NBER WORKING PAPER SERIES

\title{
DO EXTERNAL INTERVENTIONS WORK? THE CASE OF TRADE REFORM CONDITIONS IN IMF SUPPORTED PROGRAMS
}

\author{
Shang-Jin Wei \\ Zhiwei Zhang \\ Working Paper 12667 \\ http://www.nber.org/papers/w12667
NATIONAL BUREAU OF ECONOMIC RESEARCH
1050 Massachusetts Avenue
Cambridge, MA 02138 \\ November 2006
}

This is a revised version of an early paper entitled, "Evaluating the effectiveness of trade conditions in IMF-supported programs." We thank Andrew Rose for inspiring the initial idea and for helpful comments, Mary Amiti, Tamim Bayoumi, A. Bio-Tchane, Judith Dean, Dimitri Demekas, Allan Drazen, Erik De Vrijer, Steven Dunaway, Michael Hadjimichael, Simon Johnson, Kalpana Kochhar, Hans Peter Lankes, Phil McCalman, Raghuram Rajan, Tessa van der Willigen, Yi Wu, and participants of seminars at the IMF for helpful suggestions and comments, Yuanyuan Chen for excellent research assistance, and Christy Gray for able administrative support. The views expressed are those of the authors and do not necessarily reflect the views of the IMF or its policy. The views expressed herein are those of the author(s) and do not necessarily reflect the views of the National Bureau of Economic Research.

(C) 2006 by Shang-Jin Wei and Zhiwei Zhang. All rights reserved. Short sections of text, not to exceed two paragraphs, may be quoted without explicit permission provided that full credit, including (C notice, is given to the source. 
Do External Interventions Work? The Case of Trade Reform Conditions in IMF Supported Programs

Shang-Jin Wei and Zhiwei Zhang

NBER Working Paper No. 12667

November 2006

JEL No. F10,F13,F33

\begin{abstract}
$\underline{\text { ABSTRACT }}$
Trade reform conditions are common in IMF supported programs. Of the 99 countries that had IMF programs during 1993-2003, 77 had conditions on trade reforms in their programs. Since the WTO has not been found especially effective in promoting trade openness for most developing countries, it is of great interest to see if the IMF has been more effective as it combines carrots and sticks not available to the WTO. Yet, the effectiveness of trade conditions in IMF programs has not been systematically studied. Using a unique dataset, this paper provides such an assessment. It finds that trade conditions are associated with an increase in trade openness on average, but the effect comes mostly from countries that, by some measure, have a high degree of "willingness to reform."

\author{
Shang-Jin Wei \\ International Monetary Fund \\ Room 10-700 \\ 19th Street, NW \\ Washington, DC 20433 \\ and NBER \\ swei@imf.org \\ Zhiwei Zhang \\ IMF \\ Research Department \\ 700 19th Street NW \\ Washington, DC 20431 USA \\ zzhang@imf.org
}




\section{INTRODUCTION}

The International Monetary Fund and other international organizations have frequently attempted to promote structural reforms in developing countries. Both IMF programs and trade reform conditions embedded in the programs are commonplace. For example, during 1993-2003, 99 countries went through IMF programs, some with multiple ones. 77 of these countries had trade reform conditions in at least one program. Are these conditions successful in generating an increase in trade openness in developing countries? This paper aims to provide the first rigorous and comprehensive answer.

Although most economists agree that trade openness is an important element of a successful development strategy, an influential paper by Rose (2004) has cast doubt on the common presumption that the World Trade Organization (WTO) or its predecessor, the General Agreement on Trade and Tariff (GATT), has promoted global trade. Subramanian and Wei (forthcoming) also show that the GATT/WTO does not appear to have promoted trade openness for developing countries, especially those that became GATT members prior to the Uruguay Round (though it appears to have strongly promoted trade openness among developed countries). This raises an intriguing question of whether the IMF, by mixing sticks (including trade reforms in its conditionality that go beyond a country's commitments to the WTO) and carrots (providing financing through IMF supported programs if the reform conditions are met), can be more successful in prodding developing countries to engage in trade reforms.

The case of trade conditions in IMF programs also provides a window to understand whether reform conditions embedded in international financial assistance packages work in general. The efficacy of conditionality in promoting reforms is highly controversial in the literature and in policy circles. Some argue that it is entirely futile: If a country does not want to engage in serious reforms on its own for domestic political reasons, then it can always find ways to undo the substance, if not the letter, of the conditions in these programs. Others argue that the conditions are very useful precisely because they might alter domestic political forces, overcome a political impasse, and allow the necessary reform to be enacted.

The effectiveness of the trade reform conditions has not been studied in an econometrically rigorous way ${ }^{2}$. While information on IMF programs and trade reform conditions has been made available for a few countries in recent years, it is thus far not generally available for many others. By taking advantage of a unique and comprehensive database, this paper aims to fill this void. Our approach is conceptually a difference-indifferences methodology: We compute trade openness for each importer at a bilateral level before and after trade conditions were first introduced, and compare the change with either (a) those for other countries that had IMF programs but no trade conditions, or (b) those for

2 The IMF conducts periodic reviews of its trade conditions (see, for example, IMF 2001 and 2005b). Unlike the current paper, the reviews tend to adopt a case-study approach and focus on a small number of countries. 
other developing countries that had no IMF programs. To control for other factors that could affect trade openness, we embed our estimation and testing in an augmented gravity model. The augmentation includes noneconomic factors such as linguistic and colonial ties, and regional trade agreements (proposed by Frankel and Wei, 1994), year and separate importer and exporter fixed effects (needed to proxy for "multilateral resistance" proposed by Anderson and van Wincoop, 2003), and selection for non-zero trade and intra-sector firm heterogeneity (argued to be important by Helpman, Melitz, and Rubinstein, 2005).

The key findings can be summarized as follows: (a) There is evidence that trade conditions are effective on average. After accounting for a number of factors that could affect trade openness, trade conditions are associated with an increase in import volume in most statistical specifications. (b) However, the positive effect comes mostly from countries that have a high degree of "willingness to reform" by some measure. This pattern continues to hold after adjusting for a selection bias - the possibility that countries that wish to increase trade openness are more likely to agree to have trade conditions in the programs. (c) Implementation of trade conditions on paper does not imply real trade reforms. While a majority of trade conditions are recorded as having been implemented on time in the IMF's database, they do not always translate into an actual increase in trade openness.

Section 2 of this paper summarizes some salient facts about trade conditions in IMF programs. Section 3 describes a simple model to illustrate the point that external conditions on reforms can work but not in all instances. Section 4 lays out the statistical methodology, describes the data, and reports estimates for the impact of trade conditions. Section 5 presents a number of robustness checks and extensions. Section 6 offers conclusions.

\section{Some Basic Facts about Trade Conditions in IMF Programs}

It may be useful to set out some basic facts about the trade reform conditions in IMF programs. First, as noted at the beginning of the paper, these conditions are common. Figure 1 displays the counts of all IMF programs with and without trade conditions during 19932004. The height of a bar represents the total number of IMF programs in that year (e.g., 15 in 2003). The lower portion in black marks the number of programs that also carry conditions on trade reforms (e.g., 8 in 2003), whereas the upper portion in gray represents the number of programs without trade conditions (e.g., 7 in 2003). On average, about half of the programs throughout the sample have trade conditions. There is no obvious trend in the fraction of programs that carry trade conditions. In fact, it is at least as likely for a program country to have trade conditions at the end of the sample as at the beginning. 
Figure 1. Number of IMF-Supported Programs by Year

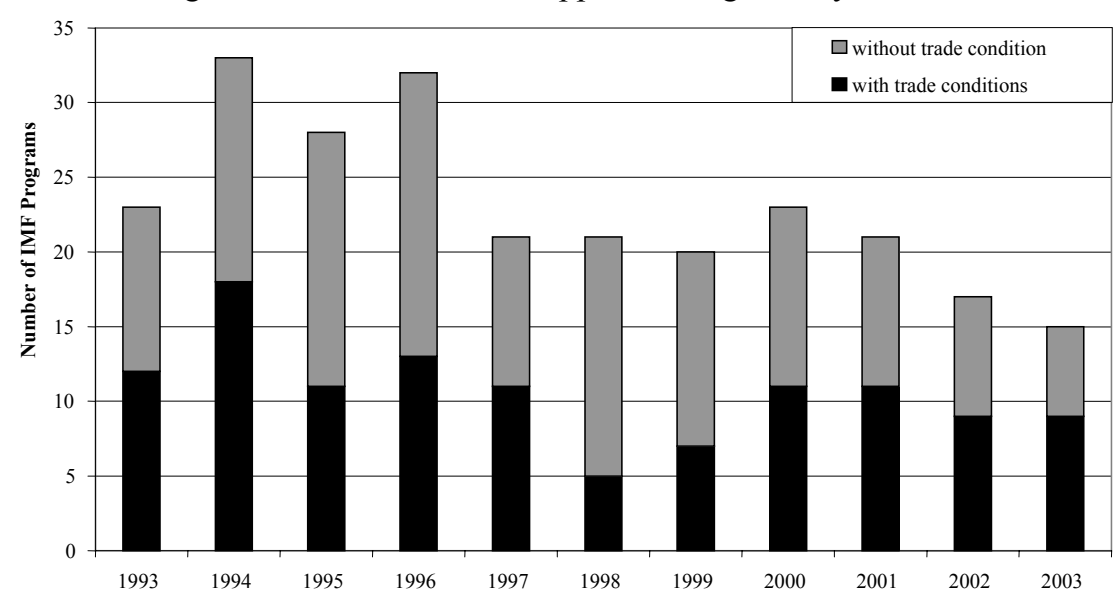

Second, the number of trade conditions as a share of total program conditions has declined in recent years, partly because conditions related to financial sector reforms have increased, and many countries have more open trade regimes in the latter part of the sample. As presented in Figure 2, the number of trade conditions per program (among programs with trade conditions) exhibits an inverse-V shape over time, peaking in 1999 (at more than 5 trade conditions per program) and then declining to 2.5 in 2003.

Figure 2. Average Number of Trade Conditions in Programs that Had Trade Conditions

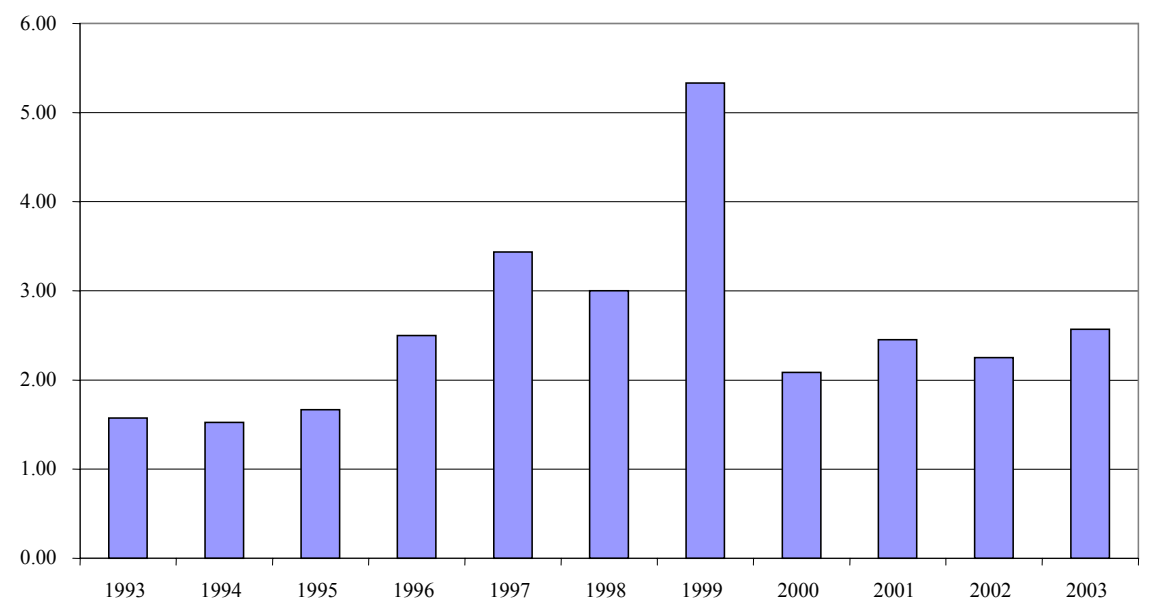

Third, the majority of trade conditions are designed to reduce market distortions and to increase trade openness. These distortions can be either tariff or nontariff measures. Among the 77 countries that had trade conditions in their programs, 55 had conditions directly on tariffs. Other conditions have supported increased efficiency including through administrative streamlining and sometimes revenue collection. In terms of the composition of all trade conditions during the sample period, more than a quarter of all trade conditions are related to tariff reductions and rationalization. Another quarter focuses on removing nontariff 
barriers such as exemptions, licensing requirements, quantitative restrictions, and other restrictions on current account transactions. ${ }^{3}$ Over time, tariff reduction and removal of quantitative restrictions as a share of total trade conditions have declined, whereas customs reforms and other measures have increased in relative importance (Figure 3).

Figure 3. Evolving Composition of Trade Conditions

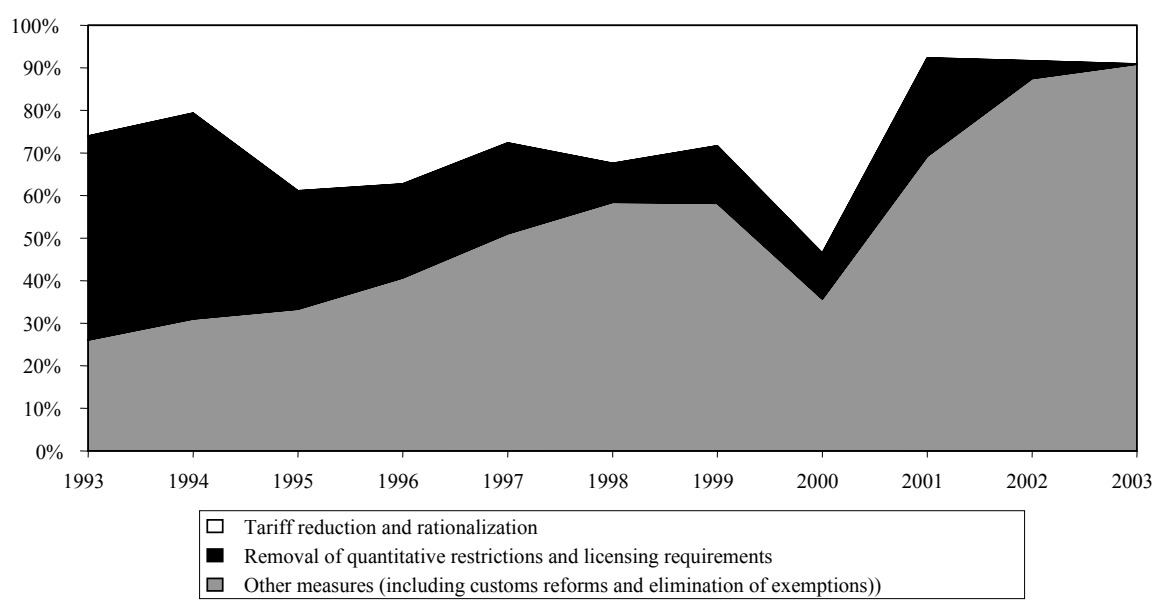

Fourth, not all conditions are of equal importance in IMF programs. The strongest form of conditions is called "prior actions"; a failure to implement them would lead to an automatic interruption of the programs. ${ }^{4}$ Approximately one-third of the trade conditions are in this category. Another strong form of conditions is "performance criteria"; loan disbursement is contingent on their fulfillment unless an explicit waiver is granted by the Executive Board. About 20 percent of the trade conditions are in this second category. The remaining trade conditions take the last and relatively weak form that is called "structural benchmarks." Their nonobservance does not automatically lead to an interruption of a program, but may affect IMF staff's judgment as to whether to recommend completion of a review. The IMF's recent review of conditionality (IMF, 2005c) suggests that prior actions are often used as a screening device by the staff to gauge the authorities' commitment to reform. This feature will be explored in discussing program ownership later.

Fifth, another interesting pattern to note is that the implementation record for trade conditions is strong on paper. About 70 percent of the trade conditions are recorded as having been implemented on time by IMF staff in the IMF's database on program conditions (Figure

\footnotetext{
${ }^{3}$ They include measures related to preshipment inspection, concessional financing for exports, export-processing zones, and other country- and industry-specific issues.

${ }^{4}$ Some prior actions are remedial actions for performance criteria or key structural benchmarks in earlier IMF-supported programs that have been missed.
} 
4). However, nominal implementation of specific measures may not always mean that policy actions have been taken with real and long-lasting effects. This paper examines the real impact of trade conditions.

Figure 4. Nominal Implementation Ratio of Trade Conditions

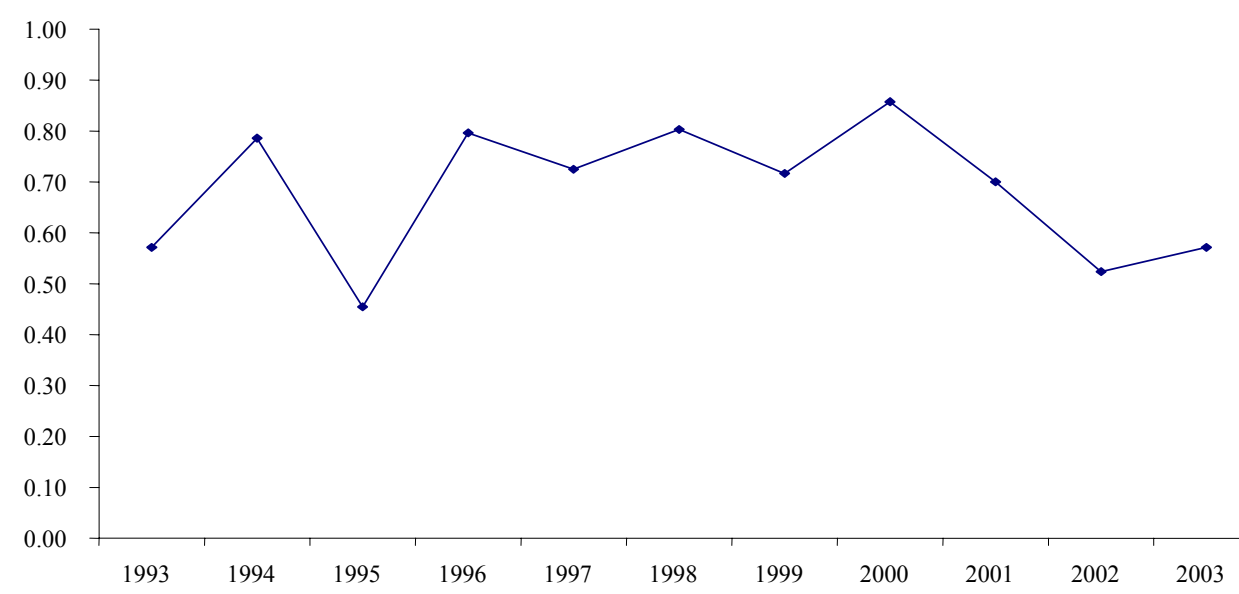

To summarize, it is not unusual for developing countries to encounter trade reform conditions in IMF supported programs. While many such conditions involve tariff reductions, most deal with removing or reducing exemptions, licensing requirement or other nontariff barriers, and administrative reforms at customs. In other words, most trade reform conditions are not easily quantifiable. Reform conditions can also be classified based on the degree of stringency (in terms of whether non-compliance by the country would lead the IMF to stop disbursement of funding). The composition of these condition types reflects in part IMF staff's subjective assessment of the likelihood that the country will follow through the reforms contained in a program. These facts provide a useful background that will guide the subsequent empirical work.

\section{A Simple Model}

To clarify how trade reform conditions embedded in an international financial assistance package may engender actual trade reforms, this section discusses a very simple model. It highlights the point that trade reform conditions by themselves may not always induce real reforms. At the same time, there are cases in which reforms take place only because an external assistance program is present.

To see how domestic factors and external assistance program interact with each other, it may be useful to summarize the domestic factors by a notion of "willingness to reform," or to use a buzzword in policy circles, the national "ownership" of a reform program. Drazen (2003) defines "ownership" as the extent to which domestic resistance to a reform can be overcome with a combination of carrots (external financing) and sticks (conditionality). A pro-reform government wants to have conditionality in IMF programs rather than to do reform on its own because the former helps it to buy support from powerful interest groups in 
the country that otherwise would veto the reform. On the other hand, the conditionality can only work if resistance to reform from the interest groups is below some threshold so that they would prefer reform with IMF financing to a combination of no reform and no IMF financing.

Suppose a country faces balance of payment difficulties and wants to borrow from the IMF. The IMF agrees to make the lending only if the country implements trade reforms (in addition to whatever else that the IMF thinks is good for the country). The policy decision in the country is made jointly by the government and a powerful interest group in the following way. The government makes a take-it-or-leave-it proposal to the interest group. The interest group has a veto power, but it cannot make a counter offer. If it agrees, the reform goes forward; if it does not, the reform dies.

The objective function of the government is the welfare of the whole economy, which leads it to favor the reform. The interest group's objective function deviates from society's welfare maximization. Its derived indirect utility function, $\mathrm{V}($.$) , can be thought of as a$ function of having the reform or not, and having the IMF program or not. In this setup, an IMF program with reform conditionality would succeed in inducing a reform that otherwise would not take place if and only if:

$\mathrm{V}($ reform, Fund program $)>\mathrm{V}($ no reform, no program $) \geq \mathrm{V}($ reform, no program $)$

In other words, if there were no IMF program, the veto-wielding interest group would prefer no reform (i.e., status quo). However, the group may prefer a combination of reform and an IMF program to a combination of no reform and no program.

Are conditions such as these two inequalities likely to hold? We now turn to a simple, micro-founded model that will make it concrete how a combination of an IMF program and reform conditions may make a difference for the success of the reform. The model makes the median voter, rather than a specific interest group, to be the pivotal decision maker. Consider a two-sector perfectly competitive, small, open economy in which each sector produces a distinct good. The first sector produces an exportable good, $\mathrm{x}$, whose output price is tied down by the world market and set to be one. The second sector produces an importcompeting good, $\mathrm{m}$, that receives a government tariff protection. The tariff-inclusive price for good $\mathrm{m}$ is $\mathrm{P}$.

Both sectors use labor as the only factor of production and have constant-returns-toscale technology. Thus, using $Y_{j}$ to denote output in sector $j$,

$$
\mathrm{Y}_{\mathrm{j}}=\mathrm{L}_{\mathrm{j}} / \mathrm{a}_{\mathrm{j}}
$$

And using L to denote the size of the labor force,

$$
\mathrm{L}_{\mathrm{x}}+\mathrm{L}_{\mathrm{m}}=\mathrm{L}
$$


Where $\mathrm{a}_{\mathrm{j}}>0, \mathrm{j}=\mathrm{x}$ and $\mathrm{m}$. Labor's initial distribution in the two sectors, $\left(\mathrm{L}^{0}{ }_{\mathrm{x}}, \mathrm{L}^{0} \mathrm{~m}\right)$, is given by history. For our discussion to be interesting, we assume that $\mathrm{L}^{0}{ }_{\mathrm{x}}<\mathrm{L}_{\mathrm{m}}^{0}$. Perfect competition in the domestic labor market ensures that

$$
\mathrm{w}_{\mathrm{j}}=\mathrm{P}_{\mathrm{j}} / \mathrm{a}_{\mathrm{j}}
$$

where $\mathrm{P}_{\mathrm{x}}=1$ by assumption and $\mathrm{P}_{\mathrm{m}}=\mathrm{P}$.

Without a loss of generality, we set $\mathrm{a}_{\mathrm{x}}=1$ and assume that the tariff on product $\mathrm{m}$ is such that the initial price on $\mathrm{m}$ is $\mathrm{P}^{0}=\mathrm{a}_{\mathrm{m}}$. Therefore, the initial wages in the two sectors are $\mathrm{w}_{\mathrm{x}}^{0}=\mathrm{w}_{\mathrm{m}}^{0}=1$.

For this small open economy, the standard trade theory tells us that free trade is socially optimal. Therefore, the objective of a reform program is to remove the tariff protection in sector $\mathrm{m}$. We need a reason for why the socially beneficial reform does not take place. For this, we employ the insight from Fernandez and Rodrik (1991) in which reallocating labor between sectors is costly and individuals face ex ante uncertainty about the exact size of the cost. Let $\mathrm{c}_{\mathrm{k}}$ be the individual-specific cost for person $\mathrm{k}$ to switch from sector $\mathrm{m}$ to sector $\mathrm{x}^{5}$. The cost is revealed when and only when the reform starts. However, the probability density function of the cost, $\mathrm{f}(\mathrm{c})$, is common for all individuals and known to them before the reform.

Suppose individuals' certainty-equivalent preferences (indirect utility functions) are identical and given by

$$
\mathrm{U}(\mathrm{P}, \mathrm{I})=\mathrm{V}(\mathrm{P}) \mathrm{I}=\mathrm{I} / \mathrm{P}^{\delta}
$$

where I is the individual's certainty-equivalent income level, and $0<\delta<1$ is a parameter.

Since we are discussing IMF-supported programs, it is reasonable to think of the country as facing a temporary negative shock that is common to all individuals in the country and that the country is unable to borrow from the international private capital market to smooth consumption. For simplicity, we think of an individual's income as her nominal wage income (which varies between the two sectors) minus an amount due to the negative shock, $\mathrm{s}$, that is common to everyone in the economy. Such a negative shock occurs as the country loses the access to the international capital market, so that it is not able to smooth its citizens' consumption on its own.

\footnotetext{
${ }^{5}$ Following Wei (1997), this represents a simplification from the original setup in Fernandez and Rodrik (1991) in which individuals have to make a general investment before learning their sector-switching cost. Wei (1997) provides a three-sector model in which gradualist and big-bang styles of reform strategies are compared.
} 


\section{$\underline{\text { Ex Post Scenario }}$}

The reform would lower $\mathrm{P}$ (and therefore the wage in sector $\mathrm{m}$ ) while leaving the price of good $\mathrm{x}$ (and the wage in sector $\mathrm{x}$ ) unchanged. This will unambiguously raise the real income for people in sector x. Everyone in Sector x therefore supports the reform. For people in sector $\mathrm{m}$, there is a difference between ex post and ex ante scenarios. Ex post, once the reform is done, individuals would choose to stay in sector $\mathrm{m}$ or switch to sector $\mathrm{x}$. An individual $\mathrm{k}$ will switch to sector $\mathrm{x}$ if her switching cost is smaller than the wage differential in the two sectors (which we label as $\mathrm{c}^{*}$ for subsequent discussion):

$$
\mathrm{c}_{\mathrm{k}}<\mathrm{w}_{\mathrm{x}}-\mathrm{w}_{\mathrm{m}} \equiv \mathrm{c}^{*}
$$

where an apostrophe denotes post-reform values. Once the reform is done, those people whose cost of switching to sector $\mathrm{x}$ is low enough may find themselves having a higher level of utility than before the reform and therefore may be glad that the reform has taken place. The rest of the people in sector $\mathrm{m}$, facing high enough switching costs, will find themselves worse off after the reform and would seek to reverse it if they could.

To be precise, an individual $\mathrm{k}$ in sector $\mathrm{m}$ will not regret the reform if and only if:

$$
\mathrm{U}\left(\mathrm{P}^{\prime}, \mathrm{w}^{\prime}{ }_{\mathrm{x}}-\mathrm{S}-\mathrm{c}_{\mathrm{k}}\right) \geq \mathrm{U}\left(\mathrm{P}^{0}, \mathrm{w}^{0}{ }_{\mathrm{m}}-\mathrm{s}\right)
$$

Or, with simplification, $\left(\mathrm{w}^{\prime}{ }_{\mathrm{x}}-\mathrm{S}-\mathrm{c}_{\mathrm{k}}\right) / \mathrm{P}^{, \delta} \geq\left(\mathrm{w}^{0}{ }_{\mathrm{m}}-\mathrm{s}\right) / \mathrm{P}^{0 \delta}$

$$
\mathrm{c}_{\mathrm{k}}<(1-\mathrm{s})\left[1-\left(\mathrm{P}^{\prime} / \mathrm{P}^{0}\right)^{\delta}\right] \quad \text { Inequality (1) }
$$

If the sum of the people in sector $\mathrm{x}$ and the people originally in sector $\mathrm{m}$ but with low enough cost to switch to sector $x$ exceeds half of the population, then the reform benefits a majority of the population by definition. The reform will not be reversed by a majority voting after it is implemented. If there exists a mechanism for ex post winners to compensate the ex post losers after the reform, then any reform that enlarges the size of the pie (after the sectorswitching cost) will not be reversed (and in fact will be supported by the population ex ante as well). Since it is not in the self-interest of the winners to compensate the losers ex post, such a compensation mechanism is not generally available, and we will rule it out for the purpose of the model exposition.

\section{$\underline{\text { Ex Ante Scenarios }}$}

How would a typical person $\mathrm{k}$ in sector $\mathrm{m}$ vote ex ante? Let us first consider the case without an IMF program. All individuals in sector $\mathrm{m}$ are identical ex ante. Person $\mathrm{k}$ in sector $\mathrm{m}$ will vote against the reform if her utility after the reform is expected to be lower than before the reform:

$$
\mathrm{V}\left(\mathrm{P}^{\prime}\right)\left\{\mathrm{F}\left(\mathrm{c}^{*}\right)\left[\left(\mathrm{w}_{\mathrm{x}}{ }^{\prime}-\mathrm{s}\right)-\int_{0} \mathrm{c}^{*} \mathrm{cf}(\mathrm{c}) / \mathrm{F}\left(\mathrm{c}^{*}\right) \mathrm{dc}\right]+\left[1-\mathrm{F}\left(\mathrm{c}^{*}\right)\right]\left(\mathrm{w}_{\mathrm{m}}{ }^{\prime}-\mathrm{s}\right)\right\}<\mathrm{V}\left(\mathrm{P}^{0}\right)\left(\mathrm{w}_{\mathrm{m}}{ }^{0}-\mathrm{s}\right)
$$


Or, after some simplification,

$$
\mathrm{F}\left(\mathrm{c}^{*}\right)+\left[1-\mathrm{F}\left(\mathrm{c}^{*}\right)\right]\left[1-\mathrm{c}^{*} /(1-\mathrm{s})\right]-\int_{0}^{\mathrm{c}^{*}} \mathrm{cf}(\mathrm{c}) \mathrm{dc}<\left(\mathrm{P}^{\prime} / \mathrm{P}^{0}\right)^{\delta} \quad \text { Inequality \#2 }
$$

Since IMF programs are meant to provide insurance to countries experiencing temporary balance of payments difficulties, especially to those that have lost access to the international capital market, we make the assumption that the IMF loan program in the model effectively eliminates the temporary shock and restores the income back to the wage level. Person $\mathrm{k}$ in sector $\mathrm{m}$ may vote for the reform with an IMF program if her expected utility with the completion of the reform together with an IMF program is higher than without the reform and the IMF program:

Or

$$
\mathrm{V}\left(\mathrm{P}^{\prime}\right)\left\{\mathrm{F}\left(\mathrm{c}^{*}\right)\left[\mathrm{w}_{\mathrm{x}}{ }^{\prime}-\int_{0} \mathrm{c}^{*} \mathrm{cf}(\mathrm{c}) / \mathrm{F}\left(\mathrm{c}^{*}\right) \mathrm{dc}\right]+\left[1-\mathrm{F}\left(\mathrm{c}^{*}\right)\right] \mathrm{w}_{\mathrm{m}}{ }^{\prime}\right\}>\mathrm{V}\left(\mathrm{P}^{0}\right)\left(\mathrm{w}_{\mathrm{m}}{ }^{0}-\mathrm{s}\right)
$$

$$
\mathrm{F}\left(\mathrm{c}^{*}\right)+\left[1-\mathrm{F}\left(\mathrm{c}^{*}\right)\right]\left[\left(1-\mathrm{c}^{*}\right) /(1-\mathrm{s})\right]-\int_{0}^{\mathrm{c}^{*}} \mathrm{cf}(\mathrm{c}) \mathrm{dc}>\left(\mathrm{P}^{\prime} / \mathrm{P}^{0}\right)^{\delta} \quad \text { Inequality \#3 }
$$

Inequalities $\# 2$ and \#3 have the same right-hand side. However, the left-hand side differs in the second term which is a function of s, the size of the shock. Any s $>0$ would make the left-hand side of \#3 greater than the left-hand side of $\# 2$. This means that if a person is to vote against the reform even with an IMF program (i.e., if Inequality \#3 is violated), then she would surely vote against the reform without an IMF program (i.e., then Inequality \#2 holds).

We focus on the set of scenarios in which Inequality \#1 holds for a sufficient number of people originally in sector $\mathrm{m}$ so that the reform genuinely benefits a majority of the population. There are still three cases to be considered:

- $\quad$ Case (a): Both inequalities \#2 and \#3 hold. In this case, the reform is blocked without an IMF program but moves forward with an IMF program.

- $\quad$ Case (b): Inequality \#2 does not hold. In this case, the reform will be implemented even without an IMF program. IMF programs play no role in inducing reforms.

- $\quad$ Case (c): Inequality \#3 is violated (which implies that Inequality \#2 holds). In this case, everyone in sector $\mathrm{m}$ (and therefore the country) will reject the reform with or without an IMF program.

Are all three cases feasible equilibria? We can verify that the answer is yes: Different combinations of the parameters could generate each of these scenarios. As an illustration, let us assume that the individual sector-switching cost, $\mathrm{c}_{\mathrm{k}}$, follows a uniform distribution over $\left[0, c^{u}\right]$, so that $\mathrm{f}(\mathrm{c})=1 / \mathrm{c}^{\mathrm{u}}$ and $\mathrm{F}\left(\mathrm{c}^{*}\right)=\mathrm{c}^{*} / \mathrm{c}^{\mathrm{u}}$. Let us further assume that $\mathrm{L}_{\mathrm{m}} / \mathrm{L}=0.55$ (the original work force in the import-competing sector constitutes a majority in the country). It can be verified that if $\mathrm{c}^{\mathrm{u}}=1, \delta=0.3, \mathrm{P}^{\prime} / \mathrm{P}=0.8$, and $\mathrm{s}=0.2$, we would be in Case (a): the reform takes place if and only if there is an IMF program. On the other hand, if $\mathrm{c}^{\mathrm{u}}=0.5, \delta=0.3$, $\mathrm{P}^{\prime} / \mathrm{P}=0.4$, and $\mathrm{s}=0.5$, we would be in Case (b): the reform takes place even without an IMF program. In contrast, if $\mathrm{c}^{\mathrm{u}}=5, \delta=0.3, \mathrm{P}^{\prime} / \mathrm{P}=0.5$, and $\mathrm{s}=0.2$, we would be in Case (c): no reform with or without an IMF program. 
This discussion suggests that one cannot take for granted that IMF programs together with conditionality on reforms will necessarily induce reforms. Indeed, as a variation of Case (c), even if a government agrees to an IMF program (in order to obtain the loan to deal with the negative shock), it may be evasive in implementing the reform or reverse the reform once the IMF program is over.

\section{EMPIRICAL EVIDENCE}

The empirical part of the paper does not test the model directly. Instead, it seeks to check if trade reform conditions are linked to changes in trade openness in countries that have had IMF programs with reform conditions. It also seeks to find proxies for how likely a country may be in Case (a) above.

\section{Statistical Specification}

The statistical framework used to assess whether trade conditions affect trade openness is an augmented gravity model. Such a model has enjoyed empirical success in terms of its ability to explain a relatively large fraction of variations in observed volumes of international trade, and has been applied to analyze the effect of a variety of policies on trade. ${ }^{6}$

The version used in this paper incorporates a number of recent theoretical insights, especially those by Anderson and van Wincoop (AvW, 2003), and Helpman, Melitz, and Rubinstein (HMR, 2005). Both papers have importer and exporter fixed effects to proxy for remoteness (Wei, 1996) or multilateral resistance (AvW, 2003). HMR (2005) propose to correct two additional selection biases: the first caused by zero bilateral trade among some countries as the gains from trade are too small to overcome the necessary costs, and the second by "an unobserved heterogeneity bias that results from the variation in the fraction of firms that export from a source to a destination country." The first bias is corrected by a standard Heckman approach (and implemented by estimating an appropriate Mills ratio). For the second bias, HMR (2005) propose a latent variable to control for the firm heterogeneity, which this paper calls "HMR variable" for short. The Mills ratio and the HMR variable are added to the analysis in this paper.

The benchmark model is specified in the following form:

$$
\mathrm{Y}_{\mathrm{i}, \mathrm{j}, \mathrm{t}}=\alpha_{1} \mathrm{IMP}_{\mathrm{i}}+\alpha_{2} \mathrm{EXP}_{\mathrm{j}}+\alpha_{3} \text { Year }_{\mathrm{t}}+\mathrm{X}_{\mathrm{i}, \mathrm{j}, \mathrm{\beta}} \beta+\gamma \mathrm{TC}_{\mathrm{i}, \mathrm{t}}+\varepsilon_{\mathrm{i}, \mathrm{j}, \mathrm{t}}
$$

The dependent variable $Y_{i, j, t}$ is $\log$ of country $i$ 's imports from country $j$ in year $\mathrm{t}$.

\footnotetext{
${ }^{6}$ Frankel and Wei (1993), Frankel, Stein, and Wei (1997), Rose (2004), and Subramanian and Wei (2003), among others.
} 
$I M P_{i, j}, E X P_{i, j}$, and $Y E A R_{t}$ are the importer, exporter, and year fixed effects, respectively. $X_{i, j, t}$ is a list of variables that previous studies have found significant in explaining the volume of trade, including log GDP, log per capita GDP, great circle distance between $i$ and $j$, dummies for common language and colonial links, shared borders, common currency, common free trade area or common market, the Mills ratio, the HMR firm heterogeneity variable, a dummy for imports by one WTO member from another member, and a dummy for imports by one WTO member from a nonmember.

$T C_{i, t}$ is a dummy variable that measures the "treatment" effect of trade conditions. It takes the value of one for country $i$ in year $t$ if the country has trade conditions in that year or any year before t during 1993-2003. For example, as 1997 was the first year that trade conditions were applied to Guinea during the sample period, the TC dummy for that country takes the value of zero during 1993-1996 and one during 1997-2003.

While separate importer and exporter fixed effects are included in this specification, they are not time-varying. Otherwise, we would not be able to identify the effect of the trade conditions (which is part of the time-varying importer fixed effects). This is a shortcoming of the specification. ${ }^{7}$ Even with only these fixed effects, identifying the effect of trade conditions presents a challenge in some cases. For example, if a country had trade conditions attached to their programs in 1993 or 1994, the TC dummy for this country would take the value of one almost throughout the sample and therefore would be highly correlated with the importer fixed effect for this country. On the other extreme, if a country had no trade conditions during the sample period until 2002 or 2003, the TC dummy would take the value of zero almost throughout the sample. In either case, the effect of the treatment of trade conditions cannot be identified. In order to solve this problem, the benchmark analysis focuses on a treatment group that started to have trade conditions no earlier than 1996 but no later than 2000 during the sample period; 27 countries fall into this category (see Table 3, Treatment Group 1, for a list).

To bring into the analysis some of the countries that had trade conditions but are excluded from the above definition of the treatment group, we also consider an alternative treatment group for countries that had trade conditions in multiple years including early in the sample period. We then compare their trade openness in the second half of the sample period versus the first half.

To estimate the treatment effect correctly, one needs to compare the treated group with a control group. Ideally, the two groups would be identical in every dimension except for one: the presence and absence of trade conditions. Program countries that did not have

\footnotetext{
${ }^{7}$ Subramanian and Wei (2003) have worked with bilateral trade equations both with timevarying importer and exporter fixed effects and with non-time-varying fixed effects. They find the two sets of fixed effects do not make a difference for the question they are studying, which is the effect of the WTO membership on members' imports from other members versus their imports from nonmembers.
} 
any trade condition in the 11 years are obvious candidates for the control group. There are 20 such countries, listed as Control Group 1 in Table 3. The augmented gravity is used to control for other ways in which treatment and control groups may be different. As a robustness check, all developing IMF member countries without IMF programs during the sample are used as an alternative control group (listed as Control Group 2 in Table 3).

\section{Data Sources and Descriptions}

The sample consists of all developing IMF member countries during 1993-2003. The data on program years and trade conditions are from a unique IMF database called Monitoring of Fund Arrangements (MONA). Documents on programs and letters of intent on some individual countries have been published on the IMF's external Web site (www.imf.org) especially since 1997. Information on the conditions and implementation records on these countries/years are publicly available.

The bilateral trade data are from the IMF's Direction of Trade database, and are deflated by the U.S. consumer price index. The data on real GDP and GDP per capita are from the World Development Indicators, the International Financial Statistics, and the Penn World Table. Control variables in the gravity regressions, such as the dummies for common language, colonial ties, shared borders, common currency, and free trade area, are derived from the web sites of Andrew Rose (www.haas.berkeley.edu/arose) and Shang-Jin Wei (www.nber.org/ wei), with minor corrections.

\section{$\underline{\text { Features of the Treatment and Control Groups }}$}

It may be useful to take a look at some main characteristics of the countries in the treatment and control groups. We first document the proportion of countries in different income groups at the beginning and end of the sample. Table 4a shows, both groups have countries at different levels of income, though the treatment group tends to have relatively more low-income countries. The subsequent analysis will take into account the effect of income on trade openness.

The average tariff level in 1997 was somewhat higher for program countries with trade conditions than for program countries without trade conditions, but somewhat lower than for countries without programs (Table 4b). The same pattern holds in 2003 as well. All three groups exhibit a decline in their tariff levels from 1997 to 2003, with the largest decrease registered by program countries with trade conditions. However, given the significant heterogeneity within each group, as measured by the standard deviation of either the level of or the change in tariffs, the pair-wise differences across the three groups are not substantial. In any case, the subsequent analysis will take into account the effect of initial conditions (as part of the importer fixed effects) on measured trade openness. 


\section{Basic Estimates of an Average Effect}

We now turn to the regression results. The specification in Column 1 of Table 5 includes separate importer, exporter, and year fixed effects. The coefficient on the trade condition variable is positive and highly significant. According to the point estimate: having trade conditions is associated with a higher import volume by 11 percent (e.g., an increase in import-to-GDP ratio from 10 to 11.1 percent). In other words, the trade conditions are effective in promoting trade, and the average impact is big.

The results for most standard gravity variables - log distance, log GDP, common border, common language, and historical/colonial links - are in line with the extant literature. One notable new result is that the coefficient on imports by one WTO member country from another member is positive (0.31) and statistically significant, but that by one WTO member from a nonmember is negative (-0.18) and statistically significant. This complements the findings in Subramanian and Wei (2003), and suggests that, for developing country WTO members, trade liberalization measures do not automatically extend to imports from nonWTO members (which are mostly also developing countries). Another interesting result is that the coefficient on the dummy for free trade agreements/customs union is not different from zero. One possible explanation is that many regional trade agreements among developing countries are not effective in reality.

In the second column of Table 5, two dummies for years during an IMF program and years after the program, respectively, are added to capture any systematic factors affecting trade that are associated with IMF programs. The coefficient on the program dummy is negative (-0.09), but that on the post-program dummy is positive (0.05). On average, for a program country without trade conditions, imports contract during the program years but then recover after the program. Taking into account these features associated with the IMF programs, the average effect of trade conditions on trade openness increases to 16 percent.

In the third column of Table 5, two measures of the importer's real exchange rate (RER) are added. A (trade-weighted) multilateral RER produces a positive coefficient: a 1 percent appreciation of the home currency tends to increase imports from the rest of the world by 0.7 percent. A bilateral RER also produces a positive coefficient: a 1 percent appreciation of the home currency against the currency of a particular trading partner above the average appreciation rate produces an additional 0.1 percent increase in imports from that trading partner above and beyond the increase in imports from the rest of the world. It is interesting to note that, once the RER variables are included, the negative coefficient on the dummy for IMF program years shrinks to -0.04 and in fact is not statistically different from zero. This suggests that the contraction in imports associated with IMF program years is likely due to a correction of previously overvalued real exchange rate in many program countries. In any case, the coefficient on the dummy for trade conditions changes very little (0.17 and statistically significant).

In the next three columns of Table 5, the model is augmented with insights from Helpman, Melitz, and Rubinstein (2004). In particular, a Mills ratio is calculated to account for non random occurrence of zero-trade among some country pairs, and an HMR variable is 
constructed to account for unobserved heterogeneity in the incidence of exporting firms across different countries. Both new regressors are positive and statistically significant, supporting the theory in Helpman, Melitz, and Rubinstein (2004). However, for the central question in this paper, the addition of these two regressors makes little difference: the estimated average effect of trade conditions is the same as before (with the point estimates slightly larger but not by a statistically significant amount).

\section{Persistence of the Effect}

Is the effect of trade conditions temporary (i.e., reversed after the expiration of the program) or long-lasting? Does the result survive once the specification deviates from assigning equal weights to imports from all trading partners? Table 6 addresses these questions. First, in all four regressions in the table, the TC dummy is now split into two dummies, representing the years in which trade conditions are applied during IMF programs, and the years after the conclusion of these programs, respectively. Second, four different weighting schemes are employed. The first column gives equal weights to all trading partners for a given importer. The last three columns weight different trading partners in proportion to their size, with the latter represented by their log GDP (Column 2), log population (Column 3 ), and log initial exports to the importing country in question (Column 4). The coefficient on trade conditions during program years is positive in columns $1-3$, ranging from 0.12 to 0.14 , but the coefficient in the last column is -0.09 . However, the coefficient on trade conditions after the expiration of the programs is positive and significant throughout the four columns, ranging from 0.13 to 0.37 . Therefore, while the initial effect is somewhat sensitive to the weighting scheme (positive and significant in most but not all cases), the effect eventually becomes stronger and statistically significant for all specifications.

As another way to trace out the trajectory of the effect of the trade conditions, the TC dummy can be decomposed into a sequence of dummies, representing, respectively, the year TCs are introduced, the first year after that, the second after that, and so on. Table 7 reports the results from this exercise. The three columns weight the observations equally, by partners' log GDP, and log population, respectively. The estimated patterns are similar across the specifications. The effect of trade conditions is nil in the year they are introduced (probably because the required reforms take time, or some programs were introduced toward the end of the year), but rise to 16-18 percent, and then come down to around 10 percent. This suggests that the effect of trade conditions is not temporary on average.

\section{$\underline{\text { Role of the Willingness to Reform }}$}

We now attempt to measure "willingness to reform" and gauge its importance in the effectiveness of trade reform conditions. This is challenging as a country's willingness to reform is not directly observable or recorded in any standard way. In this paper, we propose two proxies. The first proxy ("ownership 1") is a country's track record in implementing nontrade structural benchmarks (e.g., conditions on monetary or fiscal reforms). Specifically, we look at the percentage of non-trade structural benchmark conditions in the first program during 1993-2003 that were considered implemented by IMF staff (which is computed by us based on the information in the MONA database). Since non-implementation of these 
conditions does not automatically interrupt disbursement of IMF loans, our maintained assumption is that lower ownership of a program may lead to less implementation.

Furthermore, if a country is unwilling to implement nontrade structural benchmarks, it is also likely to be less willing to implement trade conditions.

The second proxy ("ownership 2") is our best guess of IMF staff's subjective assessment of a country's willingness to reform at the time when a program is negotiated. As discussed earlier, IMF staff has some discretion over how strong they wish to make a given condition to be. In particular, the staff tends to demand more prior actions - the strongest form of conditions - in countries that are perceived to have a high risk of going off track in subsequent periods. ${ }^{8}$ Therefore, staff's subjective assessment of ownership may be captured by the share of non-prior actions in total conditions in the first program during 1993-2003. Note that this proxy does not tell us the underlying information that leads the staff to their assessment.

Interestingly, the two proxies have a low correlation. This suggests that each may capture some different aspects of country characteristics. If the two proxies lead to opposing results, the inference on the role of ownership would be difficult. As it turns out, they produce results that basically agree with each other. To investigate how a country's willingness to reform affects the effectiveness of trade conditions, the basic model is extended to the following specification.

$$
\mathrm{Y}_{\mathrm{i}, \mathrm{j}, \mathrm{t}}=\alpha_{1} \mathrm{IMP}_{\mathrm{i}}+\alpha_{2} \mathrm{EXP}_{\mathrm{j}}+\alpha_{3} \text { Year }_{\mathrm{t}}+\mathrm{X}_{\mathrm{i}, \mathrm{j}, \mathrm{t}} \beta+\gamma_{1} \mathrm{TC}_{\mathrm{i}, \mathrm{t}}+\gamma_{2} \mathrm{TC}_{\mathrm{i}, \mathrm{t}} * \text { Ownership }_{\mathrm{i}, \mathrm{t}}+\varepsilon_{\mathrm{i}, \mathrm{j}, \mathrm{t}}
$$

Now, the effect of trade conditions is decomposed to two additive components: $\gamma_{1}+\left(\gamma_{2}\right.$ ownership). The estimation results are reported in Table 8. In the first three columns, all observations are weighted equally. With the first proxy for ownership (implementation record of nontrade structural benchmarks), $\gamma_{1}$ is not different from zero statistically, whereas $\gamma_{2}$ is positive but insignificant. With the second proxy for ownership (share of non-prior actions in total conditions) (Column 2), $\gamma_{1}$ becomes negative and significant, whereas $\gamma_{2}$ is positive and significant. When both measures of ownership are included in the same regression (in Column 3), both are positive, but only the second measure is significant. The coefficient for both proxies is numerically larger. In the last three columns, the country pair observations for given importer are weighted by trading partners' log GDP. The findings remain qualitatively unchanged.

So far, ownership is treated as a continuous variable. An alternative is to transform each proxy for ownership into two discrete cases: high and low ownership baskets using the median value of each proxy as the demarcation point. This transformation places less weight on countries that happen to have extreme values of either ownership or change in trade

\footnotetext{
${ }^{8}$ For example, "Review of the 2002 Conditionality Guidelines" (www.imf.org/external/np/pp/eng/2005/030305.pdf), page 20, "In both GRA- and PRGFsupported programs, prior actions are used as a screening device. Prior actions have continued to be used more in countries with relatively weak track records."
} 
volume, and potentially could solve the puzzle of why $\gamma_{1}$ is negative in the previous table when the second proxy is used. The regression results with high/low ownership classifications are reported in Table 9. This time, for both measures, the effect of trade conditions is zero in the case of low ownership, but positive and significant in the case of high ownership. In the latter case, trade conditions are associated with an increase in trade volume by $27-30$ percent (e.g., an increase in imports from 10 percent of GDP to 12.7-13 percent of GDP).

To summarize, the trade conditions are not associated with higher trade volume at low values of ownership. All the positive average effect of the trade conditions documented in previous tables comes from countries with sufficiently high ownership. These results support the view that country ownership is critical for the success of trade conditions. The second proxy for ownership suggests that IMF staff are often able to make informed judgments about ownership and the odds for real trade reforms at the start of a program.

\section{Robustness Checks and Extensions}

\section{Correcting for a Possible Selection Bias}

The inclusion of trade conditions in IMF programs may not be a random event. This could induce a selection bias if only countries that wanted to do trade reforms on their own would invite the IMF to include trade conditions in their programs, generating a positive association between trade conditions and trade reforms even though the former does not cause the latter. To address this possible bias, we employ a Heckman selection procedure to model the decision by the IMF to include trade conditions. Specifically, we look for some variables that are correlated with the IMF's decision to include trade reform conditions in a program. The IMF maintains a measure of the restrictiveness of every member country's trade regime - the Trade Restrictive Index (TRI) — calculated by its Policy Development and Review Department and used as a guidance indicator for country work. ${ }^{9}$ A reasonable assumption is that trade conditions are more likely to be introduced in countries that are judged to have sufficiently restrictive regimes according to the TRI index (at least during most of the sample period). This feature can be utilized to devise a correction for the possible selection bias.

We implement the correction in two steps. First, a probit regression is used to estimate the relationship between the trade conditions dummy and the TRI index. Second, an implied Mills ratio is calculated to correct for the selection bias in the main regression. The first stage Probit regression is reported in Table 10. The analysis confirms a positive relationship between a high initial value of the TRI index and an inclusion of trade conditions in a program: countries that are judged to have a relatively restrictive trade regime are more

\footnotetext{
${ }^{9}$ The IMF's TRI index aims to combine information on nontariff barriers with tariff data, and takes a value between 1 and 10, with 1 being the most open, and 10 being the most restrictive. Due to the TRI's methodological limitations, its values for individual countries are not generally reported in the staff reports. See IMF (2005b) for details.
} 
likely to incur trade reform conditions in their programs. While the TRI may not be an ideal measure of a country's trade regime, its accuracy does not affect our selection equation since we are primarily interested in forecasting how IMF selects which countries to have trade reform conditions rather than judging which countries ought to have the conditions.

Tables 11 and 12 report the second-stage regression results that correct for the selection bias in this way (i.e., including a Mills ratio variable based on the Probit regression in Table 10). While the Mills ratio variable for the selection of trade conditions is statistically significant in all regressions, its inclusion does not affect the point estimates or the statistical significance of the trade conditions variable. We conclude therefore that the selection bias (in terms of the estimated effect of trade conditions on trade openness) is not quantitatively important. The ownership effect also remains strong after accounting for the selection bias. To be precise, in Table 11 in which two continuous measures of ownership are used, while the first proxy for ownership (implementation record of nontrade structural benchmarks) is positive but insignificant, the second proxy (share of non-prior actions in all conditions) remains positive and significant. This suggests that the second proxy is a more robust predictor of subsequent effectiveness of trade conditions. For both proxies, the size of the estimated effect of willingness to reform/ownership on trade openness is broadly similar to the earlier analysis without controlling for the selection bias. In Table 12, in which high and low willingness to reform/ownership cases are represented by two indicator variables, while the Mills ratio variable for an endogenous selection of trade conditions is significant, the effects of trade conditions are positive and significant in the high ownership cases and indifferent from zero in the low ownership cases.

\section{$\underline{\text { Alternative Control and Treatment Groups }}$}

We now check the robustness of our main results to alternative control and treatment groups. The control group in the previous analysis is the set of countries that had IMF programs but no trade reform conditions. An alternative control group is all developing countries that did not go through any IMF program during 1993-2003. Table 13 repeats the basic analysis but using this alternative control group. As one can see, the findings remain the same. Trade conditions are associated with an increase in trade volume, but the positive effect comes from program countries with high degrees of ownership.

The treatment group so far is the set of countries that had at least one IMF program with trade reform conditions during the middle part of the sample (1996-2000). A different treatment group is a set of countries that had at least seven years of IMF programs with trade conditions during 1993-2003. By coincidence, the countries in this treatment group (Treatment Group 2 in Table 3) do no overlap with those in the treatment group used in the earlier regressions (Treatment Group 1 in Table 3) with the exception of one country. Therefore, this provides an independent opportunity to check whether/how trade conditions affect trade openness. The results with the new treatment group are reported in Table 14. Because most countries in this group had trade conditions in the early part of the sample period, the regressions in Table 14 compare their trade volume in the second half of the sample with the first half, conditional on other determinants of trade. The first regression shows a positive and significant average effect: countries in this group tend to have 10 percent higher trade in the second half of the sample period than in the first half. The second 
and third regressions examine the effect of ownership using the two proxies. The conclusion with this different treatment group is remarkably similar to the earlier tables: Only countries with high degrees of ownership exhibit significantly higher trade volume in the second part of the sample period.

\section{Additional Extensions and Robustness Checks}

The next extension investigates whether trade conditions work differently in countries eligible for the Poverty Reduction and Growth Facility (PRGF) versus non-PRGF countries. The PRGF programs are designed for low-income countries with both balance of payments problems and structural issues. Many of the PRGF-eligible countries are prolonged users of IMF resources. It is conceivable that trade conditions in PRGF programs might have different impact from those in non-PRGF programs. To see if this is the case, separate regressions are run for these two sets of countries. Table 15 reports the regression results for the PRGF case. In the first two columns, the coefficients on the trade conditions dummy are insignificant. In the last two columns, where the proxies for ownership and the trade conditions dummy are interacted, both proxies for ownership show positive coefficients, but only the second proxy is significant. Therefore, the central message is the same as before: The second proxy for ownership is a better predictor of the subsequent effectiveness of trade conditions, and the positive effect of trade conditions comes entirely from high-ownership programs.

Table 16 repeats the same four regressions for the non-PRGF treatment and control groups. The qualitative results are the same as before. The positive coefficients in the first two regressions are not statistically different from zero. With the first proxy for ownership, the interaction term between ownership and the trade conditions is not significant either. On the other hand, with the second proxy, the interaction term is still positive and significant.

Some of the trade conditions might have ambiguous effects on trade openness. For example, customs reforms that are designed to strengthen tariff collection could reduce trade openness. To be on the conservative side, Table 17 reports regressions excluding the three countries in the sample that do not have explicit trade liberalization measures as part of their trade conditions. This change strengthens the basic conclusion, i.e., it produces a somewhat larger effect of trade conditions on trade openness.

\section{$\underline{\text { Real Reforms Versus Nominal Implementation }}$}

It is possible that the two proxies for ownership are merely noisy estimates of whether trade conditions in the program agreements are implemented by the authorities. Conceptually, implementation of trade conditions and ownership are not the same thing: authorities with a low willingness to undertake trade reforms could implement the trade conditions to the letter of an agreement to secure financing from the IMF, but then undo the reforms by means not explicitly prohibited in the program agreement. To see this, Table 18 reports a set of regressions that include an explicit measure of the implementation of trade conditions (as assessed by the staff during reviews of the programs), interacted with the incidence of trade conditions. The coefficient on the new variable is insignificantly different from zero throughout the table. The two ownership measures are positive, though only the 
second proxy for ownership is statistically significant. This suggests that nominal implementation of trade conditions does not always translate into real and significant trade reforms, and that ownership may be a more reliable predictor for the effectiveness of trade conditions.

\section{Conclusions}

This paper aims to deepen our understanding of whether trade reform conditions in IMF programs have succeeded in raising trade openness in developing countries, something that the GATT/WTO has not been found to be particularly successful in doing. The paper finds several interesting results.

First, trade conditions are effective in increasing trade openness on average, but the effect comes almost entirely from programs for which country ownership (willingness to reform) is assessed to be high. Two proxies for ownership are constructed using information from the implementation record of nontrade structural benchmarks and staff's judgment on countries' commitment to reform as reflected in the share of prior actions in program conditions. Both proxies lead to the same conclusion that reform conditions in IMF programs do not automatically lead to real reforms, and that ownership is fundamentally important to the success of trade conditionality in increasing a country's openness to trade.

Second, implementation of trade conditions on paper does not always translate into a real and sustained increase in the openness of a country's trade regime. This suggests that many conditions may be implemented to the letter but undone in spirit by other means or reversed once a program expires.

This paper represents a first systematic study of the effectiveness of trade reform conditions. However, it does not empirically estimate the determinants of a country's willingness to reform due to lack of the relevant data. Linking measures of willingness to reform explicitly to domestic policy economy factors would be a fruitful topic for future research. 
Table 1. IMF-Supported Programs with and without Trade Conditionality, 1993-2003

\begin{tabular}{|c|c|c|c|c|c|c|c|c|c|c|c|}
\hline \multirow[b]{2}{*}{ Country } & \multicolumn{5}{|c|}{ Programs with trade conditionality } & \multicolumn{6}{|c|}{ P: Programs without trade conditions } \\
\hline & 1993 & 1994 & 1995 & 1996 & 1997 & 1998 & 1999 & 2000 & 2001 & 2002 & 2003 \\
\hline Albania & $\mathrm{T}$ & $\mathrm{T}$ & $\mathrm{T}$ & $\mathrm{T}$ & & $\mathrm{T}$ & $\mathrm{T}$ & $\mathrm{T}$ & $\mathrm{T}$ & $\mathrm{T}$ & $\mathrm{T}$ \\
\hline Algeria & $\mathrm{T}$ & $\mathrm{T}$ & $\mathrm{T}$ & $\mathrm{T}$ & $\mathrm{T}$ & $\mathrm{T}$ & & & & & \\
\hline Argentina & & & & $\mathrm{P}$ & $\mathrm{P}$ & $\mathrm{P}$ & $\mathrm{P}$ & $\mathrm{T}$ & $\mathrm{T}$ & $\mathrm{T}$ & $\mathrm{T}$ \\
\hline Armenia & & & $\mathrm{T}$ & $\mathrm{T}$ & $\mathrm{P}$ & $\mathrm{P}$ & $\mathrm{P}$ & & $\mathrm{T}$ & $\mathrm{T}$ & $\mathrm{T}$ \\
\hline Azerbaijan & & & $\mathrm{T}$ & $\mathrm{T}$ & $\mathrm{T}$ & $\mathrm{T}$ & $\mathrm{T}$ & & $\mathrm{T}$ & $\mathrm{T}$ & $\mathrm{T}$ \\
\hline Bangladesh & & & & & & & & & & & $\mathrm{T}$ \\
\hline Belarus & & & $\mathrm{P}$ & $\mathrm{P}$ & & & & & & & \\
\hline Benin & $\mathrm{T}$ & $\mathrm{T}$ & $\mathrm{T}$ & $\mathrm{T}$ & $\mathrm{T}$ & $\mathrm{T}$ & $\mathrm{T}$ & $\mathrm{T}$ & $\mathrm{P}$ & $\mathrm{P}$ & $\mathrm{P}$ \\
\hline Bolivia & & $\mathrm{P}$ & $\mathrm{P}$ & $\mathrm{P}$ & $\mathrm{P}$ & $\mathrm{T}$ & $\mathrm{T}$ & $\mathrm{T}$ & $\mathrm{T}$ & & $\mathrm{T}$ \\
\hline Bosnia and Herzegovina & & & & & & $\mathrm{T}$ & $\mathrm{T}$ & $\mathrm{T}$ & $\mathrm{T}$ & $\mathrm{T}$ & $\mathrm{T}$ \\
\hline Brazil & & & & & & $\mathrm{P}$ & $\mathrm{P}$ & $\mathrm{P}$ & $\mathrm{P}$ & $\mathrm{P}$ & \\
\hline Bulgaria & & & & $\mathrm{P}$ & $\mathrm{T}$ & $\mathrm{T}$ & $\mathrm{T}$ & $\mathrm{T}$ & $\mathrm{T}$ & $\mathrm{T}$ & $\mathrm{T}$ \\
\hline Burkina Faso & $\mathrm{T}$ & $\mathrm{T}$ & $\mathrm{T}$ & $\mathrm{T}$ & $\mathrm{T}$ & $\mathrm{T}$ & $\mathrm{T}$ & $\mathrm{T}$ & $\mathrm{T}$ & $\mathrm{T}$ & $\mathrm{P}$ \\
\hline Cambodia & & $\mathrm{T}$ & $\mathrm{T}$ & $\mathrm{T}$ & $\mathrm{T}$ & & $\mathrm{T}$ & $\mathrm{T}$ & $\mathrm{T}$ & $\mathrm{T}$ & $\mathrm{T}$ \\
\hline Cameroon & & $\mathrm{P}$ & $\mathrm{P}$ & $\mathrm{P}$ & $\mathrm{P}$ & $\mathrm{P}$ & $\mathrm{P}$ & $\mathrm{T}$ & $\mathrm{T}$ & $\mathrm{T}$ & $\mathrm{T}$ \\
\hline Cape Verde & & & & & & $\mathrm{T}$ & $\mathrm{T}$ & $\mathrm{T}$ & & $\mathrm{P}$ & $\mathrm{P}$ \\
\hline Central African Republic & & $\mathrm{T}$ & $\mathrm{T}$ & & & $\mathrm{T}$ & $\mathrm{T}$ & $\mathrm{T}$ & $\mathrm{T}$ & & \\
\hline Chad & & & $\mathrm{T}$ & $\mathrm{T}$ & $\mathrm{T}$ & $\mathrm{T}$ & $\mathrm{T}$ & $\mathrm{P}$ & $\mathrm{P}$ & $\mathrm{P}$ & $\mathrm{P}$ \\
\hline Colombia & & & & & & & $\mathrm{P}$ & $P$ & $\mathrm{P}$ & $\mathrm{P}$ & $\mathrm{P}$ \\
\hline Congo, Dem. Rep. of & & & & & & & & & & $\mathrm{T}$ & $\mathrm{T}$ \\
\hline Congo, Rep. of & & $\mathrm{T}$ & $\mathrm{T}$ & $\mathrm{P}$ & $\mathrm{P}$ & & & & & & \\
\hline Costa Rica & $\mathrm{P}$ & $\mathrm{P}$ & $\mathrm{P}$ & $\mathrm{P}$ & $\mathrm{P}$ & & & & & & \\
\hline Côte d'Ivoire & & $\mathrm{P}$ & $\mathrm{P}$ & $P$ & $\mathrm{P}$ & $\mathrm{T}$ & $\mathrm{T}$ & $\mathrm{T}$ & $\mathrm{T}$ & & \\
\hline Croatia & & $\mathrm{P}$ & $\mathrm{P}$ & $\mathrm{P}$ & $\mathrm{T}$ & $\mathrm{T}$ & $\mathrm{T}$ & $\mathrm{T}$ & $\mathrm{T}$ & $\mathrm{T}$ & $\mathrm{P}$ \\
\hline Czech Republic & $\mathrm{P}$ & $\mathrm{P}$ & & & & & & & & & \\
\hline Djibouti & & & & $\mathrm{P}$ & $\mathrm{P}$ & $\mathrm{P}$ & $\mathrm{P}$ & $\mathrm{P}$ & $\mathrm{P}$ & $\mathrm{P}$ & \\
\hline Dominica & & & & & & & & & & $\mathrm{P}$ & $\mathrm{P}$ \\
\hline Dominican Republic & $\mathrm{P}$ & $\mathrm{P}$ & & & & & & & & & $\mathrm{P}$ \\
\hline Ecuador & & $\mathrm{T}$ & $\mathrm{T}$ & & & & & $\mathrm{P}$ & $\mathrm{P}$ & & $\mathrm{P}$ \\
\hline Egypt & $\mathrm{T}$ & $\mathrm{T}$ & $\mathrm{T}$ & $\mathrm{T}$ & $\mathrm{T}$ & $\mathrm{T}$ & & & & & \\
\hline El Salvador & $\mathrm{P}$ & $\mathrm{P}$ & $P$ & $\mathrm{P}$ & $\mathrm{P}$ & $P$ & $\mathrm{P}$ & $\mathrm{P}$ & & & \\
\hline Equatorial Guinea & $\mathrm{T}$ & $\mathrm{T}$ & $\mathrm{T}$ & $\mathrm{T}$ & & & & & & & \\
\hline Estonia & $\mathrm{P}$ & $\mathrm{P}$ & $\mathrm{P}$ & $\mathrm{T}$ & $\mathrm{T}$ & $\mathrm{P}$ & $\mathrm{P}$ & $\mathrm{P}$ & $\mathrm{P}$ & & \\
\hline Ethiopia & & & & $\mathrm{T}$ & $\mathrm{T}$ & $\mathrm{T}$ & $\mathrm{T}$ & & $\mathrm{T}$ & $\mathrm{T}$ & $\mathrm{T}$ \\
\hline Gabon & & $\mathrm{P}$ & $\mathrm{T}$ & $\mathrm{T}$ & $\mathrm{T}$ & $\mathrm{T}$ & $\mathrm{T}$ & $\mathrm{T}$ & $\mathrm{T}$ & $\mathrm{T}$ & \\
\hline Gambia, The & & & & & & $\mathrm{T}$ & $\mathrm{T}$ & $\mathrm{T}$ & $\mathrm{T}$ & & \\
\hline Georgia & & & $\mathrm{P}$ & $\mathrm{T}$ & $\mathrm{T}$ & $\mathrm{T}$ & $\mathrm{T}$ & & $\mathrm{T}$ & $\mathrm{T}$ & $\mathrm{T}$ \\
\hline Ghana & & & $\mathrm{T}$ & $\mathrm{T}$ & $\mathrm{T}$ & $\mathrm{T}$ & $\mathrm{T}$ & $\mathrm{T}$ & $\mathrm{T}$ & $\mathrm{T}$ & $\mathrm{P}$ \\
\hline Guatemala & & & & & & & & & & $\mathrm{P}$ & $\mathrm{P}$ \\
\hline Guinea & & & & & $\mathrm{T}$ & $\mathrm{T}$ & $\mathrm{T}$ & $\mathrm{T}$ & $\mathrm{P}$ & $\mathrm{P}$ & $\mathrm{P}$ \\
\hline Guinea-Bissau & & & $\mathrm{T}$ & $\mathrm{T}$ & $\mathrm{T}$ & $\mathrm{T}$ & & $\mathrm{P}$ & $\mathrm{P}$ & $\mathrm{P}$ & $\mathrm{P}$ \\
\hline Guyana & & $\mathrm{T}$ & $\mathrm{T}$ & $\mathrm{T}$ & $\mathrm{T}$ & $\mathrm{T}$ & $\mathrm{T}$ & $\mathrm{T}$ & $\mathrm{T}$ & $\mathrm{P}$ & $\mathrm{P}$ \\
\hline Haiti & & & $\mathrm{T}$ & $\mathrm{T}$ & $\mathrm{T}$ & $\mathrm{T}$ & $\mathrm{T}$ & & & & \\
\hline Honduras & & & & & & & $\mathrm{T}$ & $\mathrm{T}$ & $\mathrm{T}$ & $\mathrm{T}$ & \\
\hline Hungary & $\mathrm{P}$ & $\mathrm{P}$ & & $\mathrm{T}$ & $\mathrm{T}$ & $\mathrm{T}$ & & & & & \\
\hline
\end{tabular}


Table 1. IMF-Supported Programs with and without Trade Conditionality (continued)

\begin{tabular}{|c|c|c|c|c|c|c|c|c|c|c|c|}
\hline \multirow[b]{2}{*}{ Country } & \multicolumn{5}{|c|}{ T: Programs with trade conditionality } & \multicolumn{6}{|c|}{ P: Programs without trade conditions } \\
\hline & 1993 & 1994 & 1995 & 1996 & 1997 & 1998 & 1999 & 2000 & 2001 & 2002 & 2003 \\
\hline Indonesia & & & & & $\mathrm{T}$ & $\mathrm{T}$ & $\mathrm{T}$ & $\mathrm{T}$ & $\mathrm{P}$ & $\mathrm{P}$ & $\mathrm{P}$ \\
\hline Jordan & & $\mathrm{T}$ & $\mathrm{T}$ & $\mathrm{T}$ & $\mathrm{T}$ & $\mathrm{T}$ & $\mathrm{T}$ & $\mathrm{T}$ & $\mathrm{T}$ & $\mathrm{T}$ & $\mathrm{T}$ \\
\hline Kazakhstan & & $\mathrm{T}$ & $\mathrm{T}$ & $\mathrm{T}$ & $\mathrm{T}$ & $\mathrm{T}$ & $\mathrm{T}$ & $\mathrm{T}$ & $\mathrm{T}$ & $\mathrm{T}$ & \\
\hline Kenya & $\mathrm{T}$ & $\mathrm{T}$ & & $\mathrm{P}$ & $\mathrm{P}$ & $P$ & $\mathrm{P}$ & $\mathrm{T}$ & $\mathrm{T}$ & $\mathrm{T}$ & $\mathrm{T}$ \\
\hline Korea, Republic of & & & & & $\mathrm{P}$ & $\mathrm{P}$ & $\mathrm{P}$ & $\mathrm{P}$ & & & \\
\hline Kyrgyz Republic & $\mathrm{P}$ & $\mathrm{T}$ & $\mathrm{T}$ & $\mathrm{T}$ & $\mathrm{T}$ & $\mathrm{T}$ & $\mathrm{T}$ & $\mathrm{T}$ & $\mathrm{T}$ & $\mathrm{P}$ & $\mathrm{P}$ \\
\hline Lao P.D.R. & $\mathrm{T}$ & $\mathrm{T}$ & $\mathrm{T}$ & $\mathrm{T}$ & & & & & $\mathrm{T}$ & $\mathrm{T}$ & $\mathrm{T}$ \\
\hline Latvia & $\mathrm{P}$ & $\mathrm{P}$ & $\mathrm{T}$ & $\mathrm{T}$ & $\mathrm{P}$ & $\mathrm{P}$ & $\mathrm{T}$ & $\mathrm{T}$ & $\mathrm{T}$ & $\mathrm{P}$ & \\
\hline Lesotho & & $\mathrm{P}$ & $\mathrm{P}$ & $P$ & $\mathrm{P}$ & & & & $\mathrm{P}$ & $\mathrm{P}$ & $\mathrm{P}$ \\
\hline Lithuania & $\mathrm{P}$ & $\mathrm{T}$ & $\mathrm{T}$ & $\mathrm{T}$ & $\mathrm{T}$ & & & $\mathrm{T}$ & $\mathrm{T}$ & $\mathrm{T}$ & $\mathrm{T}$ \\
\hline Macedonia, FYR & & & $\mathrm{P}$ & $\mathrm{P}$ & $\mathrm{P}$ & $\mathrm{P}$ & $\mathrm{P}$ & $\mathrm{P}$ & $\mathrm{P}$ & $\mathrm{P}$ & $\mathrm{T}$ \\
\hline Madagascar & & & & $\mathrm{T}$ & $\mathrm{T}$ & $\mathrm{T}$ & $\mathrm{T}$ & & $\mathrm{P}$ & $\mathrm{P}$ & $\mathrm{P}$ \\
\hline Malawi & & $\mathrm{P}$ & $\mathrm{T}$ & $\mathrm{T}$ & $\mathrm{T}$ & $\mathrm{T}$ & & $\mathrm{T}$ & $\mathrm{T}$ & $\mathrm{T}$ & $\mathrm{T}$ \\
\hline Mali & & & & $\mathrm{T}$ & $\mathrm{T}$ & $\mathrm{T}$ & $\mathrm{T}$ & $\mathrm{P}$ & $\mathrm{P}$ & $\mathrm{P}$ & $\mathrm{P}$ \\
\hline Mauritania & & & $\mathrm{T}$ & $\mathrm{T}$ & $\mathrm{T}$ & $\mathrm{T}$ & $\mathrm{T}$ & $\mathrm{T}$ & $\mathrm{T}$ & $\mathrm{T}$ & \\
\hline Mexico & & & $\mathrm{P}$ & $\mathrm{P}$ & $\mathrm{P}$ & & $\mathrm{P}$ & $\mathrm{P}$ & & & \\
\hline Moldova & $\mathrm{T}$ & $\mathrm{T}$ & $\mathrm{T}$ & $\mathrm{T}$ & $\mathrm{T}$ & $\mathrm{T}$ & $\mathrm{T}$ & $\mathrm{T}$ & $\mathrm{T}$ & $\mathrm{T}$ & $\mathrm{T}$ \\
\hline Mongolia & $\mathrm{T}$ & $\mathrm{T}$ & $\mathrm{T}$ & $\mathrm{T}$ & $\mathrm{P}$ & $P$ & $\mathrm{P}$ & $\mathrm{P}$ & $\mathrm{P}$ & $\mathrm{P}$ & $\mathrm{P}$ \\
\hline Mozambique & & $\mathrm{P}$ & $\mathrm{P}$ & $\mathrm{T}$ & $\mathrm{T}$ & $\mathrm{T}$ & $\mathrm{T}$ & $\mathrm{T}$ & $\mathrm{T}$ & $\mathrm{T}$ & $\mathrm{T}$ \\
\hline Nepal & & & & & & & & & & & $\mathrm{T}$ \\
\hline Nicaragua & & $\mathrm{T}$ & $\mathrm{T}$ & $\mathrm{T}$ & $\mathrm{T}$ & $\mathrm{T}$ & $\mathrm{T}$ & $\mathrm{T}$ & $\mathrm{T}$ & $\mathrm{P}$ & $\mathrm{P}$ \\
\hline Niger & & $\mathrm{P}$ & $\mathrm{P}$ & $\mathrm{T}$ & $\mathrm{T}$ & $\mathrm{T}$ & $\mathrm{T}$ & $\mathrm{P}$ & $\mathrm{P}$ & $\mathrm{P}$ & $\mathrm{P}$ \\
\hline Nigeria & & & & & & & & $\mathrm{T}$ & $\mathrm{T}$ & & \\
\hline Pakistan & $\mathrm{P}$ & $\mathrm{T}$ & $\mathrm{T}$ & $\mathrm{T}$ & $\mathrm{T}$ & $\mathrm{T}$ & $\mathrm{T}$ & $\mathrm{T}$ & $\mathrm{T}$ & $\mathrm{T}$ & $\mathrm{T}$ \\
\hline Panama & & & $\mathrm{T}$ & $\mathrm{T}$ & $\mathrm{T}$ & $\mathrm{T}$ & $\mathrm{T}$ & $\mathrm{T}$ & $\mathrm{P}$ & $\mathrm{P}$ & \\
\hline Papua New Guinea & & & $\mathrm{P}$ & $\mathrm{P}$ & $\mathrm{P}$ & & & $\mathrm{P}$ & $\mathrm{P}$ & & \\
\hline Paraguay & & & & & & & & & & & $\mathrm{T}$ \\
\hline Peru & $\mathrm{P}$ & $\mathrm{P}$ & $\mathrm{P}$ & $\mathrm{P}$ & $\mathrm{P}$ & $\mathrm{P}$ & $\mathrm{P}$ & $\mathrm{P}$ & $\mathrm{P}$ & $\mathrm{P}$ & $\mathrm{P}$ \\
\hline Philippines & & $\mathrm{T}$ & $\mathrm{T}$ & $\mathrm{T}$ & $\mathrm{T}$ & $P$ & $\mathrm{P}$ & $\mathrm{P}$ & & & \\
\hline Poland & $\mathrm{P}$ & $\mathrm{P}$ & $\mathrm{P}$ & $\mathrm{P}$ & & & & & & & \\
\hline Romania & & $\mathrm{P}$ & $\mathrm{P}$ & $\mathrm{P}$ & $\mathrm{P}$ & $\mathrm{P}$ & $\mathrm{T}$ & $\mathrm{T}$ & $\mathrm{T}$ & $\mathrm{P}$ & $\mathrm{P}$ \\
\hline Russian Federation & & & $\mathrm{T}$ & $\mathrm{T}$ & $\mathrm{T}$ & $\mathrm{T}$ & $\mathrm{T}$ & $\mathrm{T}$ & & & \\
\hline Rwanda & & & & & & $\mathrm{T}$ & $\mathrm{T}$ & $\mathrm{T}$ & $\mathrm{T}$ & $\mathrm{P}$ & $\mathrm{P}$ \\
\hline São Tomé and Príncipe & & & & & & & & $\mathrm{T}$ & $\mathrm{T}$ & $\mathrm{T}$ & $\mathrm{T}$ \\
\hline Senegal & & $\mathrm{T}$ & $\mathrm{T}$ & $\mathrm{T}$ & $\mathrm{T}$ & $\mathrm{T}$ & $\mathrm{T}$ & $\mathrm{T}$ & $\mathrm{T}$ & & $\mathrm{P}$ \\
\hline Serbia and Montenegro & & & & & & & & & & $\mathrm{T}$ & $\mathrm{T}$ \\
\hline Sierra Leone & & $\mathrm{P}$ & $\mathrm{P}$ & & & & & & $\mathrm{P}$ & $\mathrm{P}$ & $\mathrm{P}$ \\
\hline Slovak & & $\mathrm{P}$ & $\mathrm{P}$ & $\mathrm{P}$ & & & & & & & \\
\hline Sri Lanka & & & & & & & & & $\mathrm{T}$ & $\mathrm{T}$ & \\
\hline Tajikistan & & & & & & $\mathrm{T}$ & $\mathrm{T}$ & $\mathrm{T}$ & $\mathrm{T}$ & $\mathrm{P}$ & $\mathrm{P}$ \\
\hline Tanzania & & & & $\mathrm{P}$ & $\mathrm{P}$ & $\mathrm{P}$ & $\mathrm{P}$ & $\mathrm{T}$ & $\mathrm{T}$ & $\mathrm{T}$ & $\mathrm{T}$ \\
\hline Thailand & & & & & $\mathrm{P}$ & $\mathrm{P}$ & $\mathrm{P}$ & $\mathrm{P}$ & & & \\
\hline Togo & & $\mathrm{P}$ & $\mathrm{P}$ & $\mathrm{P}$ & $\mathrm{P}$ & & & & & & \\
\hline Turkey & & $\mathrm{P}$ & $\mathrm{P}$ & $\mathrm{P}$ & & & $\mathrm{P}$ & $\mathrm{P}$ & $\mathrm{P}$ & $\mathrm{T}$ & $\mathrm{T}$ \\
\hline Uganda & & $\mathrm{T}$ & $\mathrm{T}$ & $\mathrm{T}$ & $\mathrm{T}$ & $\mathrm{T}$ & $\mathrm{T}$ & $\mathrm{T}$ & & $\mathrm{P}$ & $\mathrm{P}$ \\
\hline
\end{tabular}


Table 1. IMF-Supported with and without Trade Conditionality (continued)

\begin{tabular}{|c|c|c|c|c|c|c|c|c|c|c|c|}
\hline \multirow[b]{2}{*}{ Country } & \multicolumn{5}{|c|}{ T: Programs with trade conditionality } & \multicolumn{6}{|c|}{ P: Programs without trade conditions } \\
\hline & 1993 & 1994 & 1995 & 1996 & 1997 & 1998 & 1999 & 2000 & 2001 & 2002 & 2003 \\
\hline Ukraine & & & $\mathrm{T}$ & $\mathrm{T}$ & $\mathrm{T}$ & $\mathrm{T}$ & $\mathrm{T}$ & $\mathrm{T}$ & $\mathrm{T}$ & $\mathrm{T}$ & \\
\hline Uruguay & & & & $\mathrm{P}$ & $\mathrm{P}$ & $\mathrm{P}$ & $\mathrm{P}$ & $\mathrm{T}$ & $\mathrm{T}$ & $\mathrm{T}$ & $\mathrm{T}$ \\
\hline Uzbekistan & & & $\mathrm{T}$ & $\mathrm{T}$ & $\mathrm{T}$ & & & & & & \\
\hline Venezuela & & & & $\mathrm{P}$ & $\mathrm{P}$ & & & & & & \\
\hline Vietnam & $\mathrm{T}$ & $\mathrm{T}$ & $\mathrm{T}$ & $\mathrm{T}$ & $\mathrm{T}$ & & & & $\mathrm{T}$ & $\mathrm{T}$ & $\mathrm{T}$ \\
\hline Yemen & & & & $\mathrm{P}$ & $\mathrm{T}$ & $\mathrm{T}$ & $\mathrm{T}$ & $\mathrm{T}$ & $\mathrm{T}$ & & \\
\hline Yugoslavia & & & & & & & & & $\mathrm{P}$ & $\mathrm{P}$ & \\
\hline Zambia & & & $\mathrm{P}$ & $\mathrm{P}$ & & & $\mathrm{T}$ & $\mathrm{T}$ & $\mathrm{T}$ & $\mathrm{T}$ & $\mathrm{T}$ \\
\hline Zimbabwe & & & & & & $\mathrm{T}$ & $\mathrm{T}$ & $\mathrm{T}$ & & & \\
\hline
\end{tabular}

Table 2. Summary Statistics of Trade Conditions, 1993-2003

\begin{tabular}{|c|c|c|c|c|c|c|c|c|c|c|c|c|}
\hline & 1993 & 1994 & 1995 & 1996 & 1997 & 1998 & 1999 & 2000 & 2001 & 2002 & 2003 & Total \\
\hline Fund-supported programs & 23 & 33 & 28 & 32 & 21 & 21 & 20 & 23 & 21 & 17 & 15 & 254 \\
\hline IMF-supported Programs with trade condition & 11 & 15 & 17 & 19 & 10 & 16 & 13 & 12 & 10 & 8 & 6 & 137 \\
\hline PRGF & 8 & 7 & 5 & 11 & 4 & 11 & 7 & 6 & 7 & 2 & 2 & 70 \\
\hline EFF & 1 & 3 & 2 & 5 & 3 & 3 & 2 & 0 & 0 & 1 & 0 & 20 \\
\hline SBA & 2 & 5 & 10 & 3 & 3 & 2 & 4 & 6 & 3 & 5 & 4 & 47 \\
\hline Number of trade conditions & 23 & 29 & 36 & 59 & 47 & 77 & 67 & 28 & 26 & 24 & 11 & 427 \\
\hline Prior Action (in percent) & 9 & 34 & 33 & 41 & 62 & 29 & 24 & 25 & 42 & 17 & 45 & 33 \\
\hline Structural Benchmark (in percent) & 78 & 55 & 47 & 46 & 30 & 57 & 46 & 50 & 38 & 71 & 36 & 50 \\
\hline $\begin{array}{l}\text { Performance Criteria (in } \\
\text { percent) }\end{array}$ & 13 & 10 & 19 & 14 & 9 & 14 & 30 & 25 & 19 & 13 & 18 & 17 \\
\hline Nature of trade condition & 23 & 29 & 36 & 59 & 47 & 77 & 67 & 28 & 26 & 24 & 11 & 427 \\
\hline Tariff reduction \& rationalization & 6 & 6 & 14 & 22 & 13 & 25 & 19 & 15 & 2 & 2 & 4 & 128 \\
\hline Removal of licensing requirement & 10 & 10 & 8 & 9 & 6 & 5 & 4 & 3 & 2 & 1 & 0 & 58 \\
\hline Elimination of exemptions & 2 & 0 & 0 & 6 & 3 & 7 & 5 & 1 & 1 & 0 & 1 & 26 \\
\hline Removal of quantitative restrictions & 1 & 4 & 2 & 4 & 4 & 2 & 5 & 0 & 4 & 0 & 0 & 26 \\
\hline Custom reform & 1 & 1 & 0 & 7 & 6 & 23 & 14 & 1 & 12 & 10 & 0 & 75 \\
\hline Other measures & 3 & 8 & 12 & 11 & 15 & 15 & 20 & 8 & 5 & 11 & 6 & 114 \\
\hline
\end{tabular}

Notes. PRGF $=$ Poverty Reduction and Growth Facility.

$\mathrm{EFF}=$ Extended Fund Facility

$\mathrm{SBA}=$ Stand-By Arrangement 
Table 3. List of Countries in the Sample

\begin{tabular}{|c|c|c|c|}
\hline Treatment Group 1 & Control Group 1 & Control Group 2 & Treatment Group 2 \\
\hline Argentina & Belarus & Angola & Albania \\
\hline Bolivia & Brazil & Antigua and Barbuda & Benin \\
\hline Bosnia \& Herzegovina & Colombia & Bahamas, The & Burkina Faso \\
\hline Bulgaria & Costa Rica & Kingdom of Bahrain & Cambodia \\
\hline Cameroon & Czech Republic & Barbados & Gabon \\
\hline Cape Verde & Djibouti & Belize & Ghana \\
\hline Côte 'd'Ivoire & Dominica & Burundi & Guinea-Bissau \\
\hline Croatia & Dominican Republic & Chile & Guyana \\
\hline Estonia & El Salvador & China & Jordan \\
\hline Gambia, The & Guatemala & Hong Kong SAR & Kazakhstan \\
\hline Georgia & Korea, Republic of & Comoros & Kenya \\
\hline Guinea & Mexico & Cyprus & Kyrgyz Republic \\
\hline Hungary & Papua New Guinea & Fiji & Lao P.D.R. \\
\hline Indonesia & Peru & Grenada & Latvia \\
\hline Madagascar & Poland & India & Lithuania \\
\hline Mali & Sierra Leone & Iran, I.R. of & Malawi \\
\hline Mozambique & Slovak & Israel & Mauritania \\
\hline Niger & Thailand & Jamaica & Moldova \\
\hline Nigeria & Togo & Kiribati & Mozambique \\
\hline Romania & Venezuela & Kuwait & Nicaragua \\
\hline Rwanda & & Lebanon & Pakistan \\
\hline São Tomé and Príncipe & & Liberia & Senegal \\
\hline Tajikistan & & Malaysia & Uganda \\
\hline Tanzania & & Maldives & Ukraine \\
\hline Uruguay & & Mauritius & Vietnam \\
\hline Yemen & & Morocco & \\
\hline \multirow[t]{20}{*}{ Zambia } & & Oman & \\
\hline & & Samoa & \\
\hline & & Saudi Arabia & \\
\hline & & Seychelles & \\
\hline & & Singapore & \\
\hline & & Slovenia & \\
\hline & & Solomon Islands & \\
\hline & & South Africa & \\
\hline & & St. Kitts and Nevis & \\
\hline & & St. Lucia & \\
\hline & & St. Vincent and the Gr & nadines \\
\hline & & Sudan & \\
\hline & & Suriname & \\
\hline & & Syrian Arab Republic & \\
\hline & & Tonga & \\
\hline & & Trinidad and Tobago & \\
\hline & & Tunisia & \\
\hline & & Turkmenistan & \\
\hline & & United Arab Emirates & \\
\hline & & Vanuatu & \\
\hline
\end{tabular}

Notes: The groups are defined as follows:

Treatment Group 1: countries with trade conditions during 1995-2001.

Control Group 1: countries went through IMF-supported programs without trade conditions.

Control Group 2: developing countries that did not went through programs.

Treatment Group 2: countries with trade conditions for more than 7 years.

Mozambique is in both treatment groups 1 and 2. No other country appears in more than one group. 
Table 4a. Characteristics of Countries in the Treatment and Control Groups

\begin{tabular}{|c|c|c|c|c|c|c|}
\hline & \multicolumn{6}{|c|}{$\begin{array}{l}\text { Proportion of Countries in Different Income Groups } \\
\text { (Percent, GDP measured in } 2000 \text { US\$) }\end{array}$} \\
\hline & \multicolumn{3}{|c|}{1993} & \multicolumn{3}{|c|}{2003} \\
\hline & $<800$ & $800-3000$ & $>3000$ & $<800$ & $800-3000$ & $>3000$ \\
\hline Program countries with trade conditions & 63.0 & 27.4 & 9.6 & 54.8 & 28.8 & 16.4 \\
\hline Program countries without trade conditions & 20.0 & 45.0 & 35.0 & 20.0 & 40.0 & 40.0 \\
\hline Developing countries without programs & 22.0 & 36.6 & 41.5 & 14.6 & 31.7 & 53.7 \\
\hline
\end{tabular}

Table 4b. Average Tariffs in the Treatment and Central Groups

\begin{tabular}{|c|c|c|c|c|c|c|}
\hline & \multicolumn{6}{|c|}{ Average Tariff (in percent) } \\
\hline & \multicolumn{2}{|c|}{1997} & \multicolumn{2}{|c|}{2003} & \multicolumn{2}{|c|}{ Changes from 1997 to 2003} \\
\hline & & Standard & & Standard & & Standard \\
\hline & Mean & Deviation & Mean & Deviation & Mean & Deviation \\
\hline Program countries with trade conditions & 16.8 & 8.0 & 13.5 & 6.2 & -3.3 & 6.0 \\
\hline Program countries without trade conditions & 12.9 & 4.8 & 10.3 & 4.3 & -2.6 & 3.9 \\
\hline Developing countries without programs & 17.1 & 10.7 & 13.9 & 9.6 & -3.2 & 5.3 \\
\hline
\end{tabular}


Table 5. Average Effect of Trade Conditions

\begin{tabular}{|c|c|c|c|c|c|c|}
\hline Dependent variable: real bilateral imports in log & $(1)$ & $(2)$ & $(3)$ & $(4)$ & $(5)$ & $(6)$ \\
\hline \multirow[t]{2}{*}{ Trade condition } & 0.109 & 0.162 & 0.167 & 0.117 & 0.169 & 0.177 \\
\hline & $(0.041)$ & $(0.042)$ & $(0.042)$ & $(0.041)$ & $(0.042)$ & $(0.043)$ \\
\hline \multirow[t]{2}{*}{ IMF program } & & -0.092 & -0.037 & & -0.094 & -0.041 \\
\hline & & $(0.029)$ & $(0.029)$ & & $(0.029)$ & $(0.029)$ \\
\hline \multirow[t]{2}{*}{ Post-IMF program } & & 0.046 & 0.078 & & 0.040 & 0.069 \\
\hline & & $(0.042)$ & $(0.041)$ & & $(0.042)$ & $(0.041)$ \\
\hline \multirow[t]{2}{*}{ Mills ratio for nonzero trade } & & & & 0.467 & 0.466 & 0.525 \\
\hline & & & & $(0.102)$ & $(0.102)$ & $(0.103)$ \\
\hline \multirow[t]{2}{*}{ HMR probability of nonzero trade } & & & & 0.435 & 0.441 & 0.370 \\
\hline & & & & $(0.164)$ & $(0.164)$ & $(0.163)$ \\
\hline \multirow{2}{*}{$\begin{array}{l}\text { Real exchange rate } \\
\text { (multilateral) }\end{array}$} & & & 0.006 & & & 0.006 \\
\hline & & & $(0.001)$ & & & $(0.001)$ \\
\hline \multirow{2}{*}{$\begin{array}{l}\text { Real exchange rate } \\
\text { (bilateral) }\end{array}$} & & & 0.001 & & & 0.001 \\
\hline & & & $(0.000)$ & & & $(0.000)$ \\
\hline \multirow[t]{2}{*}{ Importer WTO member, but not partner } & -0.178 & -0.158 & -0.191 & -0.159 & -0.141 & -0.170 \\
\hline & $(0.099)$ & $(0.099)$ & $(0.099)$ & $(0.098)$ & $(0.098)$ & $(0.098)$ \\
\hline \multirow{2}{*}{$\begin{array}{l}\text { Importer and partner WTO } \\
\text { members }\end{array}$} & 0.306 & 0.327 & 0.281 & 0.318 & 0.338 & 0.292 \\
\hline & $(0.067)$ & $(0.067)$ & $(0.067)$ & $(0.067)$ & $(0.067)$ & $(0.066)$ \\
\hline \multirow[t]{2}{*}{ Common border } & 0.798 & 0.797 & 0.788 & 0.669 & 0.666 & 0.690 \\
\hline & $(0.201)$ & $(0.201)$ & $(0.201)$ & $(0.213)$ & $(0.213)$ & $(0.213)$ \\
\hline \multirow[t]{2}{*}{ Ever colony } & 1.423 & 1.422 & 1.425 & 1.395 & 1.395 & 1.390 \\
\hline & $(0.220)$ & $(0.220)$ & $(0.219)$ & $(0.222)$ & $(0.222)$ & $(0.222)$ \\
\hline \multirow{2}{*}{$\begin{array}{l}\text { Common } \\
\text { colony }\end{array}$} & 1.074 & 1.073 & 1.062 & 1.064 & 1.063 & 1.049 \\
\hline & $(0.118)$ & $(0.118)$ & $(0.118)$ & $(0.118)$ & $(0.118)$ & $(0.118)$ \\
\hline \multirow[t]{2}{*}{ Common language } & 0.67 & 0.67 & 0.667 & 0.552 & 0.549 & 0.586 \\
\hline & $(0.081)$ & $(0.081)$ & $(0.081)$ & $(0.111)$ & $(0.111)$ & $(0.111)$ \\
\hline \multirow[t]{2}{*}{ Common currency } & 0.119 & 0.119 & 0.117 & -0.077 & -0.081 & -0.015 \\
\hline & $(0.249)$ & $(0.249)$ & $(0.249)$ & $(0.279)$ & $(0.279)$ & $(0.279)$ \\
\hline \multirow[t]{2}{*}{ Log distance } & -1.471 & -1.471 & -1.463 & -1.273 & -1.269 & -1.317 \\
\hline & $(0.038)$ & $(0.038)$ & $(0.037)$ & $(0.113)$ & $(0.113)$ & $(0.113)$ \\
\hline \multirow[t]{2}{*}{ Free trade area } & -0.151 & -0.154 & -0.137 & -0.357 & -0.36 & -0.358 \\
\hline & (0.099) & $(0.099)$ & $(0.098)$ & $(0.109)$ & $(0.109)$ & $(0.109)$ \\
\hline \multirow[t]{2}{*}{ Log real GDP importer } & 0.863 & 0.749 & 0.652 & 0.797 & 0.683 & 0.595 \\
\hline & $(0.139)$ & $(0.140)$ & $(0.140)$ & $(0.140)$ & $(0.141)$ & $(0.140)$ \\
\hline \multirow[t]{2}{*}{ Log real GDP exporter } & 0.409 & 0.410 & 0.424 & 0.379 & 0.379 & 0.408 \\
\hline & $(0.163)$ & $(0.163)$ & $(0.164)$ & $(0.169)$ & $(0.169)$ & $(0.170)$ \\
\hline \multirow[t]{2}{*}{ Log population importer } & -1.581 & -1.312 & -0.965 & -1.052 & -0.773 & -0.617 \\
\hline & $(0.288)$ & $(0.292)$ & $(0.294)$ & $(0.427)$ & $(0.429)$ & $(0.432)$ \\
\hline \multirow[t]{2}{*}{ Log population exporter } & -0.113 & -0.128 & 0.008 & 0.61 & 0.606 & 0.605 \\
\hline & $(0.355)$ & $(0.354)$ & $(0.353)$ & $(0.175)$ & $(0.176)$ & $(0.176)$ \\
\hline Observations & 49068 & 49068 & 49068 & 49068 & 49068 & 49068 \\
\hline R-squared & 0.71 & 0.71 & 0.71 & 0.71 & 0.71 & 0.71 \\
\hline
\end{tabular}

Note: Standard errors are based on country pair clustering. Separate importer, exporter, and year fixed effects are included but not reported. 
Table 6. "During-Program" and "Post-Program" Effects in Weighted Regressions

\begin{tabular}{|c|c|c|c|c|}
\hline Regression weights & $\begin{array}{l}\text { Equal } \\
\text { weights }\end{array}$ & $\begin{array}{l}\text { Log real } \\
\text { GDP }\end{array}$ & $\begin{array}{l}\text { Log } \\
\text { populatio }\end{array}$ & $\begin{array}{l}\text { Log real } \\
\text { imports }\end{array}$ \\
\hline \multirow[t]{2}{*}{ Trade Conditions during IMF program } & 0.140 & 0.115 & $\begin{array}{ll}\mathrm{n} & 0.118\end{array}$ & -0.095 \\
\hline & $(0.042)$ & $(0.039)$ & $(0.040)$ & $(0.035)$ \\
\hline \multirow[t]{2}{*}{ Trade conditions after IMF program } & 0.374 & 0.347 & 0.354 & 0.126 \\
\hline & $(0.073)$ & $(0.068)$ & $(0.069)$ & $(0.059)$ \\
\hline \multirow{2}{*}{$\begin{array}{l}\text { Real exchange rate } \\
\text { (multilateral) }\end{array}$} & 0.007 & 0.006 & 0.007 & 0.006 \\
\hline & $(0.001)$ & $(0.001)$ & $(0.001)$ & $(0.001)$ \\
\hline \multirow{2}{*}{$\begin{array}{l}\text { Real exchange rate } \\
\text { (bilateral) }\end{array}$} & 0.001 & 0.001 & 0.001 & 0.000 \\
\hline & $(0.000)$ & $(0.000)$ & $(0.000)$ & $(0.000)$ \\
\hline \multirow[t]{2}{*}{ IMF program } & -0.027 & -0.015 & -0.014 & 0.057 \\
\hline & $(0.029)$ & $(0.028)$ & $(0.028)$ & $(0.025)$ \\
\hline \multirow[t]{2}{*}{ Post-IMF program } & -0.003 & 0.007 & 0.011 & 0.054 \\
\hline & $(0.043)$ & $(0.041)$ & $(0.042)$ & $(0.035)$ \\
\hline \multirow[t]{2}{*}{ Importer WTO member, but not partner } & -0.206 & -0.227 & -0.215 & -0.227 \\
\hline & $(0.098)$ & $(0.097)$ & $(0.098)$ & $(0.101)$ \\
\hline \multirow{2}{*}{$\begin{array}{l}\text { Importer and partner WTO } \\
\text { members }\end{array}$} & 0.256 & 0.241 & 0.250 & 0.151 \\
\hline & $(0.066)$ & $(0.063)$ & $(0.065)$ & $(0.053)$ \\
\hline \multirow[t]{2}{*}{ Common border } & 0.689 & 0.708 & 0.719 & 0.520 \\
\hline & $(0.213)$ & $(0.208)$ & $(0.212)$ & $(0.189)$ \\
\hline \multirow[t]{2}{*}{ Ever colony } & 1.390 & 1.390 & 1.386 & 1.644 \\
\hline & $(0.222)$ & $(0.210)$ & $(0.213)$ & $(0.250)$ \\
\hline \multirow{2}{*}{$\begin{array}{l}\text { Common } \\
\text { colony }\end{array}$} & 1.049 & 1.066 & 1.054 & 1.141 \\
\hline & $(0.118)$ & $(0.117)$ & $(0.118)$ & $(0.128)$ \\
\hline \multirow[t]{2}{*}{ Common language } & 0.585 & 0.578 & 0.553 & 0.450 \\
\hline & $(0.111)$ & $(0.108)$ & $(0.108)$ & $(0.114)$ \\
\hline \multirow[t]{2}{*}{ Common currency } & -0.017 & -0.013 & -0.046 & 0.264 \\
\hline & $(0.278)$ & $(0.271)$ & $(0.271)$ & $(0.294)$ \\
\hline \multirow[t]{2}{*}{ Log distance } & -1.315 & -1.326 & -1.306 & -1.359 \\
\hline & $(0.113)$ & $(0.110)$ & $(0.110)$ & $(0.122)$ \\
\hline \multirow[t]{2}{*}{ Free trade area } & -0.359 & -0.379 & -0.368 & -0.030 \\
\hline & $(0.109)$ & $(0.105)$ & $(0.107)$ & $(0.108)$ \\
\hline \multirow[t]{2}{*}{ Log real GDP importer } & 0.601 & 0.664 & 0.661 & 1.031 \\
\hline & $(0.140)$ & $(0.135)$ & $(0.136)$ & $(0.137)$ \\
\hline \multirow[t]{2}{*}{ Log real GDP exporter } & 0.406 & 0.405 & 0.431 & 0.412 \\
\hline & $(0.170)$ & $(0.161)$ & $(0.162)$ & $(0.199)$ \\
\hline \multirow[t]{2}{*}{ Log population importer } & -0.766 & -0.856 & -0.776 & -1.441 \\
\hline & $(0.432)$ & $(0.417)$ & $(0.422)$ & $(0.431)$ \\
\hline \multirow[t]{2}{*}{ Log population exporter } & 0.607 & 0.617 & 0.576 & 0.765 \\
\hline & $(0.176)$ & $(0.170)$ & $(0.171)$ & $(0.288)$ \\
\hline \multirow[t]{2}{*}{ Mills ratio for nonzero trade } & 0.526 & 0.443 & 0.425 & 0.332 \\
\hline & $(0.103)$ & $(0.101)$ & $(0.103)$ & $(0.163)$ \\
\hline \multirow[t]{2}{*}{ HMR probability of nonzero trade } & 0.372 & 0.342 & 0.370 & 0.189 \\
\hline & $(0.163)$ & $(0.158)$ & $(0.159)$ & $(0.175)$ \\
\hline Observations & 49068 & 49068 & 49068 & 34306 \\
\hline R-squared & 0.71 & 0.72 & 0.72 & 0.76 \\
\hline
\end{tabular}

Notes: Standard errors are based on country pair clustering. Separate importer, exporter, and year fixed effects are included but not reported. 
Table 7. Time Profile of the Impact from Trade Conditions

\begin{tabular}{|c|c|c|c|}
\hline & $(1)$ & $(2)$ & (3) \\
\hline \multirow[t]{2}{*}{ Year trade conditions introduced } & 0.030 & 0.024 & 0.027 \\
\hline & $(0.044)$ & $(0.040)$ & $(0.041)$ \\
\hline \multirow{2}{*}{$\begin{array}{l}\text { 1st year after trade conditions was } \\
\text { introduced }\end{array}$} & 0.172 & 0.154 & 0.158 \\
\hline & $(0.046)$ & $(0.043)$ & $(0.044)$ \\
\hline \multirow[t]{2}{*}{ 2nd year } & 0.138 & 0.113 & 0.113 \\
\hline & $(0.049)$ & $(0.046)$ & $(0.047)$ \\
\hline \multirow[t]{2}{*}{ Third year } & 0.160 & 0.135 & 0.139 \\
\hline & $(0.048)$ & $(0.046)$ & $(0.046)$ \\
\hline \multirow[t]{2}{*}{ Fourth year } & 0.127 & 0.101 & 0.104 \\
\hline & $(0.050)$ & $(0.048)$ & $(0.048)$ \\
\hline \multirow[t]{2}{*}{ Fifth year } & 0.155 & 0.123 & 0.127 \\
\hline & $(0.053)$ & $(0.050)$ & $(0.051)$ \\
\hline \multirow[t]{2}{*}{ Sixth year } & 0.109 & 0.085 & 0.091 \\
\hline & $(0.057)$ & $(0.054)$ & $(0.055)$ \\
\hline \multirow[t]{2}{*}{ Mills ratio for non-zero trade } & 0.527 & 0.444 & 0.426 \\
\hline & $(0.103)$ & $(0.101)$ & $(0.103)$ \\
\hline \multirow[t]{2}{*}{ HMR probability of nonzero trade } & 0.363 & 0.334 & 0.362 \\
\hline & $(0.164)$ & $(0.158)$ & $(0.159)$ \\
\hline \multirow[t]{2}{*}{ Importer WTO member, but not partner } & -0.180 & -0.200 & -0.188 \\
\hline & $(0.099)$ & $(0.099)$ & $(0.099)$ \\
\hline \multirow{2}{*}{$\begin{array}{l}\text { Importer and partner WTO } \\
\text { members }\end{array}$} & 0.281 & 0.267 & 0.276 \\
\hline & $(0.068)$ & $(0.065)$ & $(0.066)$ \\
\hline \multirow[t]{2}{*}{ Common border } & 0.693 & 0.712 & 0.723 \\
\hline & $(0.213)$ & $(0.208)$ & $(0.212)$ \\
\hline \multirow[t]{2}{*}{ Ever colony } & 1.389 & 1.390 & 1.386 \\
\hline & $(0.222)$ & $(0.210)$ & $(0.213)$ \\
\hline \multirow{2}{*}{$\begin{array}{l}\text { Common } \\
\text { colony }\end{array}$} & 1.050 & 1.067 & 1.054 \\
\hline & $(0.118)$ & $(0.117)$ & $(0.118)$ \\
\hline \multirow[t]{2}{*}{ Common language } & 0.589 & 0.582 & 0.557 \\
\hline & $(0.111)$ & $(0.108)$ & $(0.109)$ \\
\hline \multirow[t]{2}{*}{ Common currency } & -0.011 & -0.008 & -0.040 \\
\hline & $(0.279)$ & $(0.271)$ & $(0.272)$ \\
\hline \multirow[t]{2}{*}{ Log distance } & -1.321 & -1.331 & -1.311 \\
\hline & $(0.113)$ & $(0.110)$ & $(0.110)$ \\
\hline \multirow[t]{2}{*}{ Free trade area } & -0.356 & -0.377 & -0.365 \\
\hline & $(0.109)$ & $(0.105)$ & $(0.107)$ \\
\hline \multirow[t]{2}{*}{ Log real GDP importer } & 0.683 & 0.742 & 0.740 \\
\hline & $(0.141)$ & $(0.136)$ & $(0.137)$ \\
\hline \multirow[t]{2}{*}{ Log real GDP exporter } & 0.408 & 0.406 & 0.432 \\
\hline & $(0.170)$ & $(0.161)$ & $(0.162)$ \\
\hline \multirow[t]{2}{*}{ Log population importer } & -0.757 & -0.841 & -0.763 \\
\hline & $(0.430)$ & $(0.414)$ & $(0.420)$ \\
\hline \multirow[t]{2}{*}{ Log population exporter } & 0.608 & 0.619 & 0.578 \\
\hline & $(0.175)$ & $(0.170)$ & $(0.171)$ \\
\hline Real exchange rate & 0.007 & 0.007 & 0.007 \\
\hline (multilateral) & $(0.001)$ & $(0.001)$ & $(0.001)$ \\
\hline Real exchange rate & 0.001 & 0.001 & 0.001 \\
\hline (bilateral) & $(0.000)$ & $(0.000)$ & $(0.000)$ \\
\hline Observations & 49068 & 49068 & 49068 \\
\hline R-squared & 0.71 & 0.72 & 0.72 \\
\hline
\end{tabular}

Notes: Standard errors are based on country pair clustering. Separate importer, exporter, and year fixed effects are included but not reported. 
Table 8. Role of Ownership

\begin{tabular}{|c|c|c|c|c|c|c|}
\hline \multirow{3}{*}{$\begin{array}{l}\text { Weighting: } \\
\text { Trade condition }\end{array}$} & \multicolumn{3}{|c|}{ Equally weighted } & \multicolumn{3}{|c|}{ Weighted by Partners' } \\
\hline & & & & \multirow{3}{*}{$\begin{array}{l}\log \\
0.030 \\
(0.103)\end{array}$} & \multicolumn{2}{|c|}{ real GDP } \\
\hline & 0.036 & -0.514 & -0.704 & & -0.578 & -0.746 \\
\hline & $(0.114)$ & $(0.199)$ & $(0.196)$ & & $(0.188)$ & $(0.188)$ \\
\hline \multirow[t]{2}{*}{ Trade condition * ownership 1} & 0.228 & & 0.260 & 0.197 & & 0.231 \\
\hline & $(0.155)$ & & $(0.152)$ & $(0.141)$ & & $(0.139)$ \\
\hline \multirow[t]{2}{*}{ Trade condition * ownership 2} & & 0.795 & 0.829 & & 0.840 & 0.870 \\
\hline & & $(0.233)$ & $(0.227)$ & & $(0.218)$ & $(0.214)$ \\
\hline \multirow[t]{2}{*}{ Importer WTO member, but not partner } & -0.173 & -0.203 & -0.208 & -0.195 & -0.226 & -0.231 \\
\hline & $(0.098)$ & $(0.098)$ & $(0.098)$ & $(0.098)$ & $(0.098)$ & $(0.098)$ \\
\hline \multirow{2}{*}{$\begin{array}{l}\text { Importer and partner WTO } \\
\text { members }\end{array}$} & 0.288 & 0.260 & 0.254 & 0.273 & 0.243 & 0.238 \\
\hline & $(0.066)$ & $(0.067)$ & $(0.067)$ & $(0.064)$ & $(0.064)$ & $(0.064)$ \\
\hline \multirow[t]{2}{*}{ Common border } & 0.691 & 0.688 & 0.689 & 0.710 & 0.707 & 0.708 \\
\hline & $(0.213)$ & $(0.213)$ & $(0.213)$ & $(0.208)$ & $(0.208)$ & $(0.208)$ \\
\hline \multirow[t]{2}{*}{ Ever colony } & 1.389 & 1.391 & 1.390 & 1.390 & 1.391 & 1.391 \\
\hline & $(0.222)$ & $(0.222)$ & $(0.222)$ & $(0.210)$ & $(0.210)$ & $(0.210)$ \\
\hline \multirow{2}{*}{$\begin{array}{l}\text { Common } \\
\text { colony }\end{array}$} & 1.050 & 1.047 & 1.047 & 1.067 & 1.064 & 1.064 \\
\hline & $(0.118)$ & $(0.118)$ & $(0.118)$ & $(0.117)$ & $(0.117)$ & $(0.117)$ \\
\hline \multirow[t]{2}{*}{ Common language } & 0.587 & 0.583 & 0.585 & 0.579 & 0.576 & 0.577 \\
\hline & $(0.111)$ & $(0.111)$ & $(0.111)$ & $(0.108)$ & $(0.107)$ & $(0.107)$ \\
\hline \multirow[t]{2}{*}{ Common currency } & -0.013 & -0.018 & -0.015 & -0.010 & -0.015 & -0.013 \\
\hline & $(0.279)$ & $(0.278)$ & $(0.279)$ & $(0.271)$ & $(0.271)$ & $(0.271)$ \\
\hline \multirow[t]{2}{*}{ Log distance } & -1.318 & -1.312 & -1.313 & -1.328 & -1.322 & -1.323 \\
\hline & $(0.113)$ & $(0.112)$ & $(0.113)$ & $(0.110)$ & $(0.109)$ & $(0.109)$ \\
\hline \multirow[t]{2}{*}{ Free trade area } & -0.358 & -0.360 & -0.359 & -0.378 & -0.380 & -0.380 \\
\hline & $(0.108)$ & $(0.109)$ & $(0.108)$ & $(0.105)$ & $(0.105)$ & $(0.105)$ \\
\hline \multirow[t]{2}{*}{ Log real GDP importer } & 0.611 & 0.658 & 0.679 & 0.673 & 0.725 & 0.744 \\
\hline & $(0.141)$ & $(0.141)$ & $(0.141)$ & $(0.136)$ & $(0.136)$ & $(0.136)$ \\
\hline \multirow{2}{*}{ Log real GDP exporter } & 0.407 & 0.410 & 0.409 & 0.406 & 0.409 & 0.408 \\
\hline & $(0.170)$ & $(0.169)$ & $(0.170)$ & $(0.161)$ & $(0.161)$ & $(0.161)$ \\
\hline \multirow[t]{2}{*}{ Log population importer } & -0.591 & -0.414 & -0.375 & -0.688 & -0.495 & -0.460 \\
\hline & $(0.431)$ & $(0.434)$ & $(0.432)$ & $(0.416)$ & $(0.417)$ & $(0.416)$ \\
\hline \multirow[t]{2}{*}{ Log population exporter } & 0.607 & 0.599 & 0.602 & 0.618 & 0.610 & 0.612 \\
\hline & $(0.176)$ & $(0.175)$ & $(0.176)$ & $(0.170)$ & $(0.170)$ & $(0.170)$ \\
\hline \multirow{2}{*}{$\begin{array}{l}\text { Real exchange rate } \\
\text { (multilateral) }\end{array}$} & 0.006 & 0.006 & 0.006 & 0.006 & 0.006 & 0.006 \\
\hline & $(0.001)$ & $(0.001)$ & $(0.001)$ & $(0.001)$ & $(0.001)$ & $(0.001)$ \\
\hline \multirow{2}{*}{$\begin{array}{l}\text { Real exchange rate } \\
\text { (bilateral) }\end{array}$} & 0.001 & 0.001 & 0.001 & 0.001 & 0.001 & 0.001 \\
\hline & $(0.000)$ & $(0.000)$ & $(0.000)$ & $(0.000)$ & $(0.000)$ & $(0.000)$ \\
\hline Mills ratio for nonzero trade & 0.527 & 0.525 & 0.526 & 0.443 & 0.442 & 0.443 \\
\hline & $(0.103)$ & $(0.103)$ & $(0.103)$ & $(0.101)$ & $(0.101)$ & $(0.101)$ \\
\hline HMR probability of nonzero trade & 0.368 & 0.377 & 0.375 & 0.338 & 0.347 & 0.345 \\
\hline & $(0.163)$ & $(0.163)$ & $(0.163)$ & $(0.158)$ & $(0.158)$ & $(0.158)$ \\
\hline IMF program & -0.039 & -0.019 & -0.015 & -0.027 & -0.006 & -0.002 \\
\hline & $(0.029)$ & $(0.029)$ & $(0.029)$ & $(0.027)$ & $(0.028)$ & $(0.028)$ \\
\hline Post IMF program & 0.075 & 0.100 & 0.107 & 0.084 & 0.113 & 0.119 \\
\hline & $(0.040)$ & $(0.043)$ & $(0.042)$ & $(0.038)$ & $(0.040)$ & $(0.039)$ \\
\hline Observations & 49068 & 49068 & 49068 & 49068 & 49068 & 49068 \\
\hline R-squared & 0.71 & 0.71 & 0.71 & 0.72 & 0.72 & 0.72 \\
\hline
\end{tabular}

Notes: Standard errors are based on country pair clustering. Separate importer, exporter, and year fixed effects are included but not reported. 
Table 9. High versus Low Ownership Relative to Median

\begin{tabular}{|c|c|c|}
\hline \multirow{2}{*}{ Trade condition * High ownership 1} & $(1)$ & (2) \\
\hline & $\begin{array}{r}0.297 \\
(0.050)\end{array}$ & \\
\hline Trade condition $*$ Low ownership 1 & $\begin{array}{r}0.034 \\
(0.060)\end{array}$ & \\
\hline Trade condition * High ownership 2 & & $\begin{array}{r}0.272 \\
(0.061)\end{array}$ \\
\hline Trade condition * Low ownership 2 & & $\begin{array}{r}0.076 \\
(0.051)\end{array}$ \\
\hline Importer WTO member, but not partner & $\begin{array}{r}-0.162 \\
(0.097)\end{array}$ & $\begin{array}{r}-0.206 \\
(0.098)\end{array}$ \\
\hline $\begin{array}{l}\text { Importer and partner WTO } \\
\text { members }\end{array}$ & $\begin{array}{r}0.297 \\
(0.066)\end{array}$ & $\begin{array}{r}0.258 \\
(0.067)\end{array}$ \\
\hline Common border & $\begin{array}{r}0.691 \\
(0.213)\end{array}$ & $\begin{array}{r}0.689 \\
(0.213)\end{array}$ \\
\hline Ever colony & $\begin{array}{r}1.388 \\
(0.222)\end{array}$ & $\begin{array}{r}1.390 \\
(0.222)\end{array}$ \\
\hline $\begin{array}{l}\text { Common } \\
\text { colony }\end{array}$ & $\begin{array}{r}1.048 \\
(0.118)\end{array}$ & $\begin{array}{r}1.047 \\
(0.118)\end{array}$ \\
\hline Common language & $\begin{array}{r}0.586 \\
(0.111)\end{array}$ & $\begin{array}{r}0.585 \\
(0.111)\end{array}$ \\
\hline Common currency & $\begin{array}{r}-0.015 \\
(0.279)\end{array}$ & $\begin{array}{l}-0.016 \\
(0.278)\end{array}$ \\
\hline Log distance & $\begin{array}{l}-1.315 \\
(0.113)\end{array}$ & $\begin{array}{l}-1.314 \\
(0.113)\end{array}$ \\
\hline Free trade area & $\begin{array}{r}-0.359 \\
(0.109)\end{array}$ & $\begin{array}{r}-0.359 \\
(0.109)\end{array}$ \\
\hline Log real GDP importer & $\begin{array}{r}0.587 \\
(0.140)\end{array}$ & $\begin{array}{r}0.620 \\
(0.140)\end{array}$ \\
\hline Log real GDP exporter & $\begin{array}{r}0.408 \\
(0.170)\end{array}$ & $\begin{array}{r}0.411 \\
(0.169)\end{array}$ \\
\hline Log population importer & $\begin{array}{r}-0.619 \\
(0.431)\end{array}$ & $\begin{array}{l}-0.506 \\
(0.432)\end{array}$ \\
\hline Log population exporter & $\begin{array}{r}0.605 \\
(0.176)\end{array}$ & $\begin{array}{r}0.600 \\
(0.175)\end{array}$ \\
\hline $\begin{array}{l}\text { Real exchange rate } \\
\text { (multilateral) }\end{array}$ & $\begin{array}{r}0.006 \\
(0.001)\end{array}$ & $\begin{array}{r}0.006 \\
(0.001)\end{array}$ \\
\hline $\begin{array}{l}\text { Real exchange rate } \\
\text { (bilateral) }\end{array}$ & $\begin{array}{r}0.001 \\
(0.000)\end{array}$ & $\begin{array}{r}0.001 \\
(0.000)\end{array}$ \\
\hline IMF program & $\begin{array}{l}-0.026 \\
(0.029)\end{array}$ & $\begin{array}{r}-0.033 \\
(0.029)\end{array}$ \\
\hline Post IMF program & $\begin{array}{r}0.075 \\
(0.041)\end{array}$ & $\begin{array}{r}0.086 \\
(0.042)\end{array}$ \\
\hline Mills ratio for non-zero trade & $\begin{array}{r}0.532 \\
(0.103)\end{array}$ & $\begin{array}{r}0.526 \\
(0.103)\end{array}$ \\
\hline HMR probability of nonzero trade & $\begin{array}{r}0.372 \\
(0.163)\end{array}$ & $\begin{array}{r}0.373 \\
(0.163)\end{array}$ \\
\hline IMF program & $\begin{array}{r}-0.026 \\
(0.029)\end{array}$ & $\begin{array}{l}-0.033 \\
(0.029)\end{array}$ \\
\hline Post IMF program & $\begin{array}{r}0.075 \\
(0.041)\end{array}$ & $\begin{array}{r}0.086 \\
(0.042)\end{array}$ \\
\hline Observations & 49068 & 49068 \\
\hline R-squared & 0.71 & 0.71 \\
\hline
\end{tabular}

Notes: Standard errors are based on country pair clustering. Separate importer, exporter, and year fixed effects are included but not reported. 
Table 10: Predicting Which Countries/Years Have Trade Conditions Using IMF's Trade Restrictive Index (Probit Regression)

Dependent variable: dummy for trade conditions

Trade Restrictive Index

Constant

$-1.568$

Pseudo R2 
Table 11: Accounting for Endogenous Trade Condtions Using Trade Restrictive Index

\begin{tabular}{|c|c|c|c|}
\hline & $(1)$ & $(2)$ & (3) \\
\hline \multirow[t]{2}{*}{ Trade condition } & 0.068 & -0.069 & -0.642 \\
\hline & $(0.046)$ & $(0.117)$ & $(0.199)$ \\
\hline \multirow[t]{2}{*}{ Trade condition $*$ ownership 1} & & 0.224 & \\
\hline & & $(0.155)$ & \\
\hline \multirow[t]{2}{*}{ Trade condition $*$ ownership 2} & & & 0.811 \\
\hline & & & $(0.233)$ \\
\hline \multirow[t]{2}{*}{ Importer WTO member, but not partner } & -0.197 & -0.200 & -0.232 \\
\hline & $(0.098)$ & $(0.098)$ & $(0.098)$ \\
\hline \multirow[t]{2}{*}{ Importer and partner WTO members } & 0.266 & 0.262 & 0.232 \\
\hline & $(0.066)$ & $(0.067)$ & $(0.067)$ \\
\hline \multirow[t]{2}{*}{ Common border } & 0.691 & 0.692 & 0.689 \\
\hline & $(0.213)$ & $(0.213)$ & $(0.213)$ \\
\hline \multirow[t]{2}{*}{ Ever colony } & 1.390 & 1.389 & 1.391 \\
\hline & $(0.222)$ & $(0.222)$ & $(0.222)$ \\
\hline \multirow[t]{2}{*}{ Common colony } & 1.049 & 1.050 & 1.046 \\
\hline & $(0.118)$ & $(0.118)$ & $(0.118)$ \\
\hline \multirow[t]{2}{*}{ Common language } & 0.586 & 0.587 & 0.584 \\
\hline & $(0.111)$ & $(0.111)$ & $(0.111)$ \\
\hline \multirow[t]{2}{*}{ Common currency } & -0.015 & -0.013 & -0.018 \\
\hline & $(0.279)$ & $(0.279)$ & $(0.279)$ \\
\hline \multirow[t]{2}{*}{ Log distance } & -1.317 & -1.319 & -1.313 \\
\hline & $(0.113)$ & $(0.113)$ & $(0.112)$ \\
\hline \multirow[t]{2}{*}{ Free trade area } & -0.359 & -0.359 & -0.361 \\
\hline & $(0.109)$ & $(0.108)$ & $(0.109)$ \\
\hline \multirow[t]{2}{*}{ Log real GDP importer } & 0.567 & 0.582 & 0.630 \\
\hline & $(0.141)$ & $(0.142)$ & $(0.141)$ \\
\hline \multirow[t]{2}{*}{ Log real GDP exporter } & 0.409 & 0.408 & 0.411 \\
\hline & $(0.170)$ & $(0.170)$ & $(0.169)$ \\
\hline \multirow[t]{2}{*}{ Log population importer } & -0.654 & -0.627 & -0.448 \\
\hline & $(0.432)$ & $(0.431)$ & $(0.434)$ \\
\hline \multirow[t]{2}{*}{ Log population exporter } & 0.605 & 0.608 & 0.600 \\
\hline & $(0.176)$ & $(0.176)$ & $(0.176)$ \\
\hline \multirow[t]{2}{*}{ Real exchange rate (multilateral) } & 0.007 & 0.006 & 0.006 \\
\hline & $(0.001)$ & $(0.001)$ & $(0.001)$ \\
\hline \multirow[t]{2}{*}{ Real exchange rate (bilateral) } & 0.001 & 0.001 & 0.001 \\
\hline & 0.000 & 0.000 & 0.000 \\
\hline \multirow[t]{2}{*}{ Mills ratio for TC selection } & -0.115 & -0.114 & -0.120 \\
\hline & $(0.031)$ & $(0.031)$ & $(0.031)$ \\
\hline \multirow[t]{2}{*}{ Mills ratio for nonzero trade } & 0.526 & 0.527 & 0.526 \\
\hline & $(0.103)$ & $(0.103)$ & $(0.103)$ \\
\hline \multirow[t]{2}{*}{ HMR probability of nonzero trade } & 0.369 & 0.367 & 0.376 \\
\hline & $(0.163)$ & $(0.163)$ & $(0.163)$ \\
\hline \multirow[t]{2}{*}{ IMF program } & -0.033 & -0.03 & -0.010 \\
\hline & $(0.029)$ & $(0.029)$ & $(0.029)$ \\
\hline \multirow[t]{2}{*}{ Post IMF program } & 0.087 & 0.092 & 0.119 \\
\hline & $(0.041)$ & $(0.040)$ & $(0.042)$ \\
\hline Observations & 49068 & 49068 & 49068 \\
\hline R-squared & 0.71 & 0.71 & 0.71 \\
\hline
\end{tabular}

Note 1: Standard errors are based on country pair clustering. Separate importer, exporter, and year fixed effects are included but not reported. 
Table 12. Discrete Measures of Ownership, with Correction for Selection Bias

\begin{tabular}{|c|c|c|}
\hline & $(1)$ & $(2)$ \\
\hline \multirow[t]{2}{*}{ Trade condition * High ownership 1} & 0.188 & \\
\hline & $(0.052)$ & \\
\hline \multirow[t]{2}{*}{ Trade condition * Low ownership 1} & -0.077 & \\
\hline & $(0.064)$ & \\
\hline \multirow[t]{2}{*}{ Trade condition * High ownership 2} & & 0.162 \\
\hline & & $(0.063)$ \\
\hline \multirow[t]{2}{*}{ Trade condition * Low ownership 2} & & -0.039 \\
\hline & & $(0.054)$ \\
\hline \multirow[t]{2}{*}{ Mills ratio for non-zero trade } & 0.533 & 0.527 \\
\hline & $(0.103)$ & $(0.103)$ \\
\hline \multirow[t]{2}{*}{ HMR probability of nonzero trade } & 0.372 & 0.373 \\
\hline & $(0.163)$ & $(0.163)$ \\
\hline \multirow[t]{2}{*}{ Importer WTO member, but not partner } & -0.189 & -0.235 \\
\hline & $(0.098)$ & $(0.099)$ \\
\hline \multirow{2}{*}{$\begin{array}{l}\text { Importer and partner WTO } \\
\text { members }\end{array}$} & 0.271 & 0.230 \\
\hline & $(0.066)$ & $(0.067)$ \\
\hline \multirow[t]{2}{*}{ Common border } & 0.692 & 0.690 \\
\hline & $(0.213)$ & $(0.213)$ \\
\hline \multirow[t]{2}{*}{ Ever colony } & 1.388 & 1.390 \\
\hline & $(0.222)$ & $(0.222)$ \\
\hline Common & 1.048 & 1.047 \\
\hline \multirow{3}{*}{$\begin{array}{l}\text { Colony } \\
\text { Common language }\end{array}$} & $(0.118)$ & $(0.118)$ \\
\hline & 0.586 & 0.585 \\
\hline & $(0.111)$ & $(0.111)$ \\
\hline \multirow[t]{2}{*}{ Common currency } & -0.015 & -0.016 \\
\hline & $(0.279)$ & $(0.279)$ \\
\hline \multirow[t]{2}{*}{ Log distance } & -1.316 & -1.315 \\
\hline & $(0.113)$ & $(0.113)$ \\
\hline \multirow[t]{2}{*}{ Free trade area } & -0.360 & -0.360 \\
\hline & $(0.109)$ & $(0.109)$ \\
\hline \multirow[t]{2}{*}{ Log real GDP importer } & 0.558 & 0.591 \\
\hline & $(0.141)$ & $(0.140)$ \\
\hline \multirow[t]{2}{*}{ Log real GDP exporter } & 0.408 & 0.412 \\
\hline & $(0.170)$ & $(0.169)$ \\
\hline \multirow[t]{2}{*}{ Log population importer } & -0.656 & -0.541 \\
\hline & $(0.431)$ & $(0.432)$ \\
\hline \multirow[t]{2}{*}{ Log population exporter } & 0.606 & 0.600 \\
\hline & $(0.176)$ & $(0.175)$ \\
\hline \multirow{2}{*}{$\begin{array}{l}\text { Real exchange rate } \\
\text { (multilateral) }\end{array}$} & 0.007 & 0.007 \\
\hline & $(0.001)$ & $(0.001)$ \\
\hline Real exchange rate & 0.001 & 0.001 \\
\hline (bilateral) & 0.000 & 0.000 \\
\hline IMF program & -0.018 & -0.024 \\
\hline & $(0.029)$ & $(0.029)$ \\
\hline Post-IMF program & 0.093 & 0.104 \\
\hline & $(0.041)$ & $(0.042)$ \\
\hline Mills ratio for $\mathrm{TC}$ selection & -0.116 & -0.118 \\
\hline & $(0.031)$ & $(0.031)$ \\
\hline Observations & 49068 & 49068 \\
\hline R-squared & 0.71 & 0.71 \\
\hline
\end{tabular}

Notes: Standard errors are based on country pair clustering. Separate importer, exporter, and year fixed effects are included but not reported. 
Table 13. Alternative Control Group

(Sample: Treatment Group 1 and Control Group 2 in Table 3)

\begin{tabular}{|c|c|c|c|}
\hline & (1) & (2) & (3) \\
\hline \multirow[t]{2}{*}{ Trade condition } & 0.145 & -0.045 & -0.546 \\
\hline & $(0.045)$ & $(0.133)$ & $(0.228)$ \\
\hline \multirow[t]{2}{*}{ Trade Condition * Ownership 1} & & 0.286 & \\
\hline & & $(0.186)$ & \\
\hline \multirow[t]{2}{*}{ Trade Condition * Ownership 2} & & & 0.763 \\
\hline & & & $(0.253)$ \\
\hline \multirow[t]{2}{*}{ Importer WTO member, but not partner } & -0.22 & -0.223 & -0.241 \\
\hline & $(0.087)$ & $(0.087)$ & $(0.087)$ \\
\hline \multirow{2}{*}{$\begin{array}{l}\text { Importer and partner WTO } \\
\text { members }\end{array}$} & 0.216 & 0.213 & 0.196 \\
\hline & $(0.054)$ & $(0.054)$ & $(0.054)$ \\
\hline \multirow[t]{2}{*}{ Common border } & 0.199 & 0.205 & 0.228 \\
\hline & $(0.276)$ & $(0.276)$ & $(0.276)$ \\
\hline \multirow[t]{2}{*}{ Ever colony } & 1.433 & 1.431 & 1.432 \\
\hline & $(0.205)$ & $(0.205)$ & $(0.205)$ \\
\hline \multirow{2}{*}{$\begin{array}{l}\text { Common } \\
\text { colony }\end{array}$} & 0.633 & 0.633 & 0.632 \\
\hline & $(0.090)$ & $(0.090)$ & $(0.090)$ \\
\hline \multirow[t]{2}{*}{ Common language } & 0.183 & 0.19 & 0.213 \\
\hline & $(0.097)$ & $(0.096)$ & $(0.098)$ \\
\hline \multirow[t]{2}{*}{ Common currency } & -0.209 & -0.197 & -0.156 \\
\hline & $(0.251)$ & $(0.251)$ & $(0.252)$ \\
\hline \multirow[t]{2}{*}{ Log distance } & -1.235 & -1.244 & -1.28 \\
\hline & $(0.101)$ & $(0.100)$ & $(0.102)$ \\
\hline \multirow[t]{2}{*}{ Free trade area } & -0.112 & -0.111 & -0.109 \\
\hline & $(0.110)$ & $(0.110)$ & $(0.110)$ \\
\hline \multirow[t]{2}{*}{ Log real GDP importer } & 0.959 & 0.966 & 1.009 \\
\hline & $(0.153)$ & $(0.153)$ & $(0.154)$ \\
\hline \multirow[t]{2}{*}{ Log real GDP exporter } & 0.300 & 0.298 & 0.310 \\
\hline & $(0.179)$ & $(0.179)$ & $(0.178)$ \\
\hline \multirow[t]{2}{*}{ Log real population importer } & -0.576 & -0.577 & -0.601 \\
\hline & $(0.151)$ & $(0.151)$ & $(0.151)$ \\
\hline \multirow[t]{2}{*}{ Log real population exporter } & 1.439 & 1.427 & 1.310 \\
\hline & $(0.439)$ & $(0.439)$ & $(0.441)$ \\
\hline \multirow{2}{*}{$\begin{array}{l}\text { Bilateral real exchange } \\
\text { rate }\end{array}$} & 0.000 & 0.000 & 0.000 \\
\hline & $(0.000)$ & $(0.000)$ & $(0.000)$ \\
\hline \multirow[t]{2}{*}{ Mills ratio for nonzero trade } & 0.360 & 0.361 & 0.359 \\
\hline & $(0.093)$ & $(0.093)$ & $(0.093)$ \\
\hline \multirow[t]{2}{*}{ HMR probability of nonzero trade } & 0.811 & 0.797 & 0.742 \\
\hline & $(0.148)$ & $(0.148)$ & $(0.151)$ \\
\hline \multirow[t]{2}{*}{ IMF program } & -0.220 & -0.204 & -0.173 \\
\hline & $(0.054)$ & $(0.052)$ & $(0.057)$ \\
\hline \multirow[t]{2}{*}{ Post IMF program } & -0.043 & -0.024 & 0.020 \\
\hline & $(0.083)$ & $(0.079)$ & $(0.088)$ \\
\hline Observations & 56755 & 56755 & 56755 \\
\hline R-squared & 0.73 & 0.73 & 0.73 \\
\hline
\end{tabular}

Notes: Standard errors are based on country pair clustering. Separate importer, exporter, and year fixed effects are included but not reported. 
Table 14. Continuous Trade Reforms

(Sample: Treatment group 2 and control group 1 in Table A3.)

\begin{tabular}{|c|c|c|c|}
\hline & (1) & (2) & (3) \\
\hline \multirow[t]{2}{*}{ Trade condition } & 0.096 & -0.309 & -0.490 \\
\hline & $(0.048)$ & $(0.089)$ & $(0.482)$ \\
\hline \multirow[t]{2}{*}{ Trade condition * Ownership 1} & & 0.590 & \\
\hline & & $(0.113)$ & \\
\hline \multirow[t]{2}{*}{ Trade condition * Ownership 2} & & & 0.601 \\
\hline & & & $(0.491)$ \\
\hline \multirow[t]{2}{*}{ Importer WTO member, but not partner } & -0.159 & -0.137 & -0.167 \\
\hline & $(0.101)$ & $(0.101)$ & $(0.101)$ \\
\hline \multirow[t]{2}{*}{ Importer and partner WTO members } & 0.343 & 0.361 & 0.334 \\
\hline & $(0.066)$ & $(0.066)$ & $(0.067)$ \\
\hline \multirow[t]{2}{*}{ Common border } & 0.810 & 0.799 & 0.808 \\
\hline & $(0.220)$ & $(0.220)$ & $(0.220)$ \\
\hline \multirow[t]{2}{*}{ Ever colony } & 1.338 & 1.338 & 1.339 \\
\hline & $(0.210)$ & $(0.211)$ & $(0.210)$ \\
\hline \multirow[t]{2}{*}{ Common colony } & 1.255 & 1.255 & 1.254 \\
\hline & $(0.116)$ & $(0.116)$ & $(0.116)$ \\
\hline \multirow[t]{2}{*}{ Common language } & 0.599 & 0.587 & 0.597 \\
\hline & $(0.118)$ & $(0.118)$ & $(0.118)$ \\
\hline \multirow[t]{2}{*}{ Common currency } & -0.024 & -0.046 & -0.028 \\
\hline & $(0.311)$ & $(0.311)$ & $(0.311)$ \\
\hline \multirow[t]{2}{*}{ Log distance } & -1.246 & -1.228 & -1.243 \\
\hline & $(0.129)$ & $(0.129)$ & $(0.129)$ \\
\hline \multirow[t]{2}{*}{ Free trade area } & 0.384 & 0.381 & 0.384 \\
\hline & $(0.127)$ & $(0.127)$ & $(0.127)$ \\
\hline \multirow[t]{2}{*}{ Log real GDP importer } & 0.554 & 0.616 & 0.566 \\
\hline & $(0.173)$ & $(0.173)$ & $(0.173)$ \\
\hline \multirow[t]{2}{*}{ Log real GDP exporter } & 0.472 & 0.471 & 0.471 \\
\hline & $(0.195)$ & $(0.195)$ & $(0.195)$ \\
\hline \multirow[t]{2}{*}{ Log real population importer } & 0.146 & -0.02 & 0.196 \\
\hline & $(0.506)$ & $(0.506)$ & $(0.507)$ \\
\hline \multirow[t]{2}{*}{ Log real population exporter } & 0.551 & 0.539 & 0.549 \\
\hline & $(0.194)$ & $(0.194)$ & $(0.194)$ \\
\hline \multirow[t]{2}{*}{ Bilateral real exchange rate } & -0.001 & -0.001 & -0.001 \\
\hline & $(0.000)$ & $(0.000)$ & $(0.000)$ \\
\hline \multirow[t]{2}{*}{ Mills ratio for nonzero trade } & 0.183 & 0.182 & 0.182 \\
\hline & $(0.104)$ & $(0.104)$ & $(0.104)$ \\
\hline \multirow[t]{2}{*}{ HMR probability of nonzero trade } & 0.293 & 0.319 & 0.297 \\
\hline & $(0.186)$ & $(0.186)$ & $(0.186)$ \\
\hline \multirow[t]{2}{*}{ IMF program } & -0.163 & -0.156 & -0.161 \\
\hline & $(0.044)$ & $(0.044)$ & $(0.044)$ \\
\hline \multirow[t]{2}{*}{ Post IMF program } & -0.196 & -0.191 & -0.193 \\
\hline & $(0.054)$ & $(0.054)$ & $(0.054)$ \\
\hline Observations & 41375 & 41375 & 41375 \\
\hline R-squared & 0.71 & 0.71 & 0.71 \\
\hline
\end{tabular}

Note 1: Standard errors are based on country pair clustering. Separate importer, exporter, and year fixed effects are included but not reported. 
Table 15. PRGF Programs

\begin{tabular}{|c|c|c|c|c|}
\hline & (1) & (2) & (3) & $(4)$ \\
\hline \multirow[t]{2}{*}{ Trade condition } & 0.002 & -0.001 & -0.189 & -0.523 \\
\hline & $(0.069)$ & $(0.069)$ & $(0.153)$ & $(0.259)$ \\
\hline \multirow[t]{2}{*}{ Trade condition $*$ ownership 1} & & & 0.298 & \\
\hline & & & $(0.196)$ & \\
\hline \multirow[t]{2}{*}{ Trade condition * ownership 2} & & & & 0.589 \\
\hline & & & & $(0.291)$ \\
\hline \multirow[t]{2}{*}{ IMF program } & 0.193 & 0.201 & 0.211 & 0.230 \\
\hline & $(0.058)$ & $(0.057)$ & $(0.056)$ & $(0.059)$ \\
\hline \multirow[t]{2}{*}{ Post IMF program } & 0.321 & 0.333 & 0.359 & 0.361 \\
\hline & $(0.097)$ & $(0.097)$ & $(0.093)$ & $(0.099)$ \\
\hline \multirow[t]{2}{*}{ Importer WTO member, but not partner } & -0.588 & -0.534 & -0.539 & -0.522 \\
\hline & $(0.201)$ & $(0.193)$ & $(0.193)$ & $(0.193)$ \\
\hline \multirow[t]{2}{*}{ Importer and partner WTO members } & 0.241 & 0.184 & 0.179 & 0.199 \\
\hline & $(0.134)$ & $(0.134)$ & $(0.134)$ & $(0.134)$ \\
\hline \multirow[t]{2}{*}{ Common border } & 0.862 & 0.870 & 0.873 & 0.862 \\
\hline & $(0.331)$ & $(0.353)$ & $(0.353)$ & $(0.353)$ \\
\hline \multirow[t]{2}{*}{ Ever colony } & 1.764 & 1.273 & 1.272 & 1.277 \\
\hline & $(0.371)$ & $(0.430)$ & $(0.430)$ & $(0.430)$ \\
\hline \multirow[t]{2}{*}{ Common colony } & 0.769 & 0.886 & 0.890 & 0.885 \\
\hline & $(0.145)$ & $(0.141)$ & $(0.141)$ & $(0.141)$ \\
\hline \multirow[t]{2}{*}{ Common language } & 0.292 & 0.467 & 0.469 & 0.459 \\
\hline & $(0.122)$ & $(0.169)$ & $(0.169)$ & $(0.168)$ \\
\hline \multirow[t]{2}{*}{ Common currency } & 0.488 & 0.749 & 0.751 & 0.736 \\
\hline & $(0.243)$ & $(0.325)$ & $(0.325)$ & $(0.325)$ \\
\hline \multirow[t]{2}{*}{ Log distance } & -1.696 & -2.068 & -2.070 & -2.057 \\
\hline & $(0.087)$ & $(0.198)$ & $(0.198)$ & $(0.198)$ \\
\hline \multirow[t]{2}{*}{ Free trade area } & 1.668 & 1.539 & 1.529 & 1.539 \\
\hline & $(0.288)$ & $(0.301)$ & $(0.302)$ & $(0.301)$ \\
\hline \multirow[t]{2}{*}{ Log real GDP importer } & 0.243 & 0.283 & 0.293 & 0.263 \\
\hline & $(0.228)$ & $(0.226)$ & $(0.226)$ & $(0.226)$ \\
\hline \multirow[t]{2}{*}{ Log real GDP exporter } & -0.133 & -0.042 & -0.046 & -0.039 \\
\hline & $(0.272)$ & $(0.273)$ & $(0.275)$ & $(0.272)$ \\
\hline \multirow[t]{2}{*}{ Log population importer } & -2.353 & -3.679 & -3.662 & -3.333 \\
\hline & $(0.601)$ & $(0.790)$ & $(0.791)$ & $(0.804)$ \\
\hline \multirow[t]{2}{*}{ Log population exporter } & 1.648 & 1.325 & 1.331 & 1.312 \\
\hline & $(0.590)$ & $(0.307)$ & $(0.309)$ & $(0.306)$ \\
\hline \multirow[t]{2}{*}{ Real exchange rate (multilateral) } & 0.000 & 0.000 & 0.000 & 0.000 \\
\hline & $(0.001)$ & $(0.001)$ & $(0.001)$ & $(0.001)$ \\
\hline \multirow[t]{2}{*}{ Real exchange rate (bilateral) } & 0.000 & 0.000 & 0.000 & 0.000 \\
\hline & $(0.000)$ & $(0.000)$ & $(0.000)$ & $(0.000)$ \\
\hline \multirow[t]{2}{*}{ Mills ratio for nonzero trade } & & 2.047 & 2.047 & 2.042 \\
\hline & & $(0.201)$ & $(0.201)$ & $(0.202)$ \\
\hline \multirow[t]{2}{*}{ HMR probability of nonzero trade } & & 0.299 & 0.295 & 0.317 \\
\hline & & $(0.273)$ & $(0.273)$ & $(0.272)$ \\
\hline Observations & 17519 & 17519 & 17519 & 17519 \\
\hline R-squared & 0.64 & 0.64 & 0.64 & 0.64 \\
\hline
\end{tabular}

Note 1: Standard errors are based on country pair clustering. Separate importer, exporter, and year fixed effects are included but not reported. 
Table 16. Non-PRGF Programs

\begin{tabular}{|c|c|c|c|c|}
\hline & $(1)$ & $(2)$ & (3) & $(4)$ \\
\hline \multirow[t]{2}{*}{ Trade condition } & 0.054 & 0.056 & -0.005 & -0.445 \\
\hline & $(0.059)$ & $(0.059)$ & $(0.182)$ & $(0.308)$ \\
\hline \multirow[t]{2}{*}{ Trade condition * ownership 1} & & & 0.089 & \\
\hline & & & $(0.264)$ & \\
\hline \multirow[t]{2}{*}{ Trade condition * ownership 2} & & & & 0.580 \\
\hline & & & & $(0.345)$ \\
\hline \multirow[t]{2}{*}{ IMF program } & -0.043 & -0.044 & -0.044 & -0.033 \\
\hline & $(0.035)$ & $(0.035)$ & $(0.035)$ & $(0.035)$ \\
\hline \multirow[t]{2}{*}{ Post IMF program } & 0.041 & 0.039 & 0.037 & 0.054 \\
\hline & $(0.047)$ & $(0.047)$ & $(0.047)$ & $(0.047)$ \\
\hline \multirow[t]{2}{*}{ Importer WTO member, but not partner } & 0.003 & 0.006 & 0.005 & -0.026 \\
\hline & $(0.110)$ & $(0.110)$ & $(0.110)$ & $(0.111)$ \\
\hline \multirow{2}{*}{$\begin{array}{l}\text { Importer and partner WTO } \\
\text { members }\end{array}$} & 0.193 & 0.197 & 0.197 & 0.166 \\
\hline & $(0.075)$ & $(0.075)$ & $(0.075)$ & $(0.076)$ \\
\hline \multirow[t]{2}{*}{ Common border } & 0.588 & 0.354 & 0.355 & 0.356 \\
\hline & $(0.225)$ & $(0.238)$ & $(0.238)$ & $(0.238)$ \\
\hline \multirow[t]{2}{*}{ Ever colony } & 1.163 & 1.187 & 1.187 & 1.188 \\
\hline & $(0.271)$ & $(0.272)$ & $(0.272)$ & $(0.272)$ \\
\hline \multirow{2}{*}{$\begin{array}{l}\text { Common } \\
\text { colony }\end{array}$} & 2.369 & 2.360 & 2.360 & 2.358 \\
\hline & $(0.224)$ & $(0.225)$ & $(0.225)$ & $(0.225)$ \\
\hline \multirow[t]{2}{*}{ Common language } & 0.884 & 0.637 & 0.638 & 0.640 \\
\hline & $(0.115)$ & $(0.146)$ & $(0.147)$ & $(0.146)$ \\
\hline \multirow[t]{2}{*}{ Common currency } & 1.276 & 0.847 & 0.850 & 0.851 \\
\hline & $(0.962)$ & $(0.975)$ & $(0.976)$ & $(0.974)$ \\
\hline \multirow[t]{2}{*}{ Log distance } & -1.317 & -0.941 & -0.942 & -0.944 \\
\hline & $(0.042)$ & $(0.134)$ & $(0.134)$ & $(0.134)$ \\
\hline \multirow[t]{2}{*}{ Free trade area } & -0.058 & -0.128 & -0.127 & -0.128 \\
\hline & $(0.100)$ & $(0.107)$ & $(0.107)$ & $(0.107)$ \\
\hline \multirow[t]{2}{*}{ Log real GDP importer } & 0.204 & 0.108 & 0.099 & 0.195 \\
\hline & $(0.217)$ & $(0.218)$ & $(0.217)$ & $(0.220)$ \\
\hline \multirow[t]{2}{*}{ Log real GDP exporter } & 0.651 & 0.568 & 0.568 & 0.570 \\
\hline & $(0.196)$ & $(0.204)$ & $(0.204)$ & $(0.204)$ \\
\hline \multirow[t]{2}{*}{ Log population importer } & -1.401 & -0.330 & -0.345 & -0.248 \\
\hline & $(0.454)$ & $(0.589)$ & $(0.590)$ & $(0.585)$ \\
\hline \multirow[t]{2}{*}{ Log population exporter } & -0.838 & 0.284 & 0.285 & 0.285 \\
\hline & $(0.426)$ & $(0.205)$ & $(0.205)$ & $(0.205)$ \\
\hline \multirow{2}{*}{$\begin{array}{l}\text { Real exchange rate } \\
\text { (multilateral) }\end{array}$} & 0.012 & 0.012 & 0.012 & 0.012 \\
\hline & $(0.001)$ & $(0.001)$ & $(0.001)$ & $(0.001)$ \\
\hline \multirow{2}{*}{$\begin{array}{l}\text { Real exchange rate } \\
\text { (bilateral) }\end{array}$} & 0.002 & 0.002 & 0.002 & 0.002 \\
\hline & $(0.000)$ & $(0.000)$ & $(0.000)$ & $(0.000)$ \\
\hline \multirow[t]{2}{*}{ Mills ratio for nonzero trade } & & 0.106 & 0.106 & 0.111 \\
\hline & & $(0.116)$ & $(0.116)$ & $(0.117)$ \\
\hline \multirow[t]{2}{*}{ HMR probability of nonzero trade } & & 0.598 & 0.596 & 0.594 \\
\hline & & $(0.196)$ & $(0.196)$ & $(0.196)$ \\
\hline Observations & 31232 & 31232 & 31232 & 31232 \\
\hline R-squared & 0.76 & 0.76 & 0.76 & 0.76 \\
\hline
\end{tabular}

Notes: Standard errors are based on country pair clustering. Separate importer, exporter, and year fixed effects are included but not reported. 
Table 17. Excluding Programs without Explicit Trade Liberalization Conditions

\begin{tabular}{|c|c|c|c|c|}
\hline & $(1)$ & $(2)$ & $(3)$ & $(4)$ \\
\hline \multirow[t]{2}{*}{ Trade condition } & 0.163 & 0.173 & 0.063 & -0.494 \\
\hline & $(0.046)$ & $(0.046)$ & $(0.124)$ & $(0.211)$ \\
\hline \multirow[t]{2}{*}{ Trade condition $*$ ownership 1} & & & 0.184 & \\
\hline & & & $(0.175)$ & \\
\hline \multirow[t]{2}{*}{ Trade condition * ownership 2} & & & & 0.781 \\
\hline & & & & $(0.253)$ \\
\hline \multirow[t]{2}{*}{ IMF program } & -0.042 & -0.046 & -0.043 & -0.025 \\
\hline & $(0.030)$ & $(0.030)$ & $(0.030)$ & $(0.031)$ \\
\hline \multirow[t]{2}{*}{ Post IMF program } & 0.090 & 0.081 & 0.086 & 0.107 \\
\hline & $(0.042)$ & $(0.042)$ & $(0.041)$ & $(0.043)$ \\
\hline \multirow[t]{2}{*}{ Importer WTO member, but not partner } & -0.202 & -0.180 & -0.184 & -0.218 \\
\hline & $(0.100)$ & $(0.100)$ & $(0.100)$ & $(0.100)$ \\
\hline \multirow[t]{2}{*}{ Importer and partner WTO members } & 0.297 & 0.307 & 0.302 & 0.270 \\
\hline & $(0.067)$ & $(0.067)$ & $(0.067)$ & $(0.067)$ \\
\hline \multirow[t]{2}{*}{ Common border } & 0.797 & 0.674 & 0.676 & 0.674 \\
\hline & $(0.213)$ & $(0.226)$ & $(0.226)$ & $(0.226)$ \\
\hline \multirow[t]{2}{*}{ Ever colony } & 1.470 & 1.442 & 1.442 & 1.443 \\
\hline & $(0.233)$ & $(0.235)$ & $(0.235)$ & $(0.235)$ \\
\hline \multirow[t]{2}{*}{ Common colony } & 1.044 & 1.028 & 1.028 & 1.025 \\
\hline & $(0.127)$ & $(0.127)$ & $(0.127)$ & $(0.127)$ \\
\hline \multirow[t]{2}{*}{ Common language } & 0.693 & 0.587 & 0.589 & 0.586 \\
\hline & $(0.086)$ & $(0.116)$ & $(0.116)$ & $(0.116)$ \\
\hline \multirow[t]{2}{*}{ Common currency } & -0.104 & -0.270 & -0.268 & -0.269 \\
\hline & $(0.254)$ & $(0.285)$ & $(0.285)$ & $(0.285)$ \\
\hline \multirow[t]{2}{*}{ Log distance } & -1.451 & -1.269 & -1.270 & -1.267 \\
\hline & $(0.038)$ & $(0.116)$ & $(0.116)$ & $(0.116)$ \\
\hline \multirow[t]{2}{*}{ Free trade area } & -0.140 & -0.348 & -0.347 & -0.350 \\
\hline & $(0.099)$ & $(0.109)$ & $(0.109)$ & $(0.109)$ \\
\hline \multirow[t]{2}{*}{ Log real GDP importer } & 0.670 & 0.604 & 0.609 & 0.668 \\
\hline & $(0.141)$ & $(0.142)$ & $(0.142)$ & $(0.143)$ \\
\hline \multirow[t]{2}{*}{ Log real GDP exporter } & 0.401 & 0.376 & 0.376 & 0.378 \\
\hline & $(0.169)$ & $(0.175)$ & $(0.176)$ & $(0.175)$ \\
\hline \multirow[t]{2}{*}{ Log population importer } & -1.011 & -0.557 & -0.527 & -0.346 \\
\hline & $(0.300)$ & $(0.441)$ & $(0.440)$ & $(0.444)$ \\
\hline \multirow[t]{2}{*}{ Log population exporter } & -0.073 & 0.609 & 0.611 & 0.605 \\
\hline & $(0.364)$ & $(0.180)$ & $(0.180)$ & $(0.180)$ \\
\hline \multirow[t]{2}{*}{ Real exchange rate (multilateral) } & 0.006 & 0.006 & 0.006 & 0.006 \\
\hline & $(0.001)$ & $(0.001)$ & $(0.001)$ & $(0.001)$ \\
\hline \multirow[t]{2}{*}{ Real exchange rate (bilateral) } & 0.001 & 0.001 & 0.001 & 0.001 \\
\hline & $(0.000)$ & $(0.000)$ & $(0.000)$ & $(0.000)$ \\
\hline \multirow[t]{2}{*}{ Mills ratio for nonzero trade } & & 0.494 & 0.495 & 0.494 \\
\hline & & $(0.104)$ & $(0.104)$ & $(0.104)$ \\
\hline \multirow[t]{2}{*}{ HMR probability of nonzero trade } & & 0.413 & 0.411 & 0.417 \\
\hline & & $(0.168)$ & $(0.168)$ & $(0.168)$ \\
\hline Observations & 45878 & 45878 & 45878 & 45878 \\
\hline R-squared & 0.71 & 0.71 & 0.71 & 0.71 \\
\hline
\end{tabular}

Note 1: Standard errors are based on country pair clustering. Separate importer, exporter, and year fixed effects are included but not reported. 
Table 18. Nominal Implementation of Trade Conditions

\begin{tabular}{|c|c|c|c|c|}
\hline & (1) & $(2)$ & (3) & $(4)$ \\
\hline \multirow[t]{2}{*}{ Trade condition } & 0.158 & 0.180 & 0.060 & -0.540 \\
\hline & $(0.102)$ & $(0.102)$ & $(0.151)$ & $(0.194)$ \\
\hline \multirow{2}{*}{$\begin{array}{l}\text { Trade condition * Implementation of trade } \\
\text { conditions }\end{array}$} & 0.011 & -0.005 & -0.040 & 0.028 \\
\hline & $(0.113)$ & $(0.113)$ & $(0.106)$ & $(0.110)$ \\
\hline \multirow[t]{2}{*}{ Trade condition * ownership 1} & & & 0.238 & \\
\hline & & & $(0.146)$ & \\
\hline \multirow[t]{2}{*}{ Trade condition * ownership 2} & & & & 0.801 \\
\hline & & & & $(0.226)$ \\
\hline \multirow[t]{2}{*}{ Importer WTO member, but not partner } & -0.191 & -0.170 & -0.174 & -0.202 \\
\hline & $(0.099)$ & $(0.098)$ & $(0.098)$ & $(0.098)$ \\
\hline \multirow{2}{*}{$\begin{array}{l}\text { Importer and partner WTO } \\
\text { members }\end{array}$} & 0.281 & 0.291 & 0.287 & 0.260 \\
\hline & $(0.067)$ & $(0.066)$ & $(0.066)$ & $(0.067)$ \\
\hline \multirow[t]{2}{*}{ Common border } & 0.788 & 0.689 & 0.690 & 0.689 \\
\hline & $(0.201)$ & $(0.213)$ & $(0.213)$ & $(0.213)$ \\
\hline \multirow[t]{2}{*}{ Ever colony } & 1.425 & 1.390 & 1.389 & 1.391 \\
\hline & $(0.219)$ & $(0.222)$ & $(0.222)$ & $(0.222)$ \\
\hline \multirow{2}{*}{$\begin{array}{l}\text { Common } \\
\text { colony }\end{array}$} & 1.063 & 1.049 & 1.049 & 1.047 \\
\hline & $(0.118)$ & $(0.118)$ & $(0.118)$ & $(0.118)$ \\
\hline \multirow[t]{2}{*}{ Common language } & 0.667 & 0.586 & 0.586 & 0.584 \\
\hline & $(0.081)$ & $(0.111)$ & $(0.111)$ & $(0.111)$ \\
\hline \multirow[t]{2}{*}{ Common currency } & 0.117 & -0.015 & -0.014 & -0.017 \\
\hline & $(0.249)$ & $(0.278)$ & $(0.278)$ & $(0.278)$ \\
\hline \multirow[t]{2}{*}{ Log distance } & -1.463 & -1.317 & -1.317 & -1.313 \\
\hline & $(0.038)$ & $(0.113)$ & $(0.113)$ & $(0.112)$ \\
\hline \multirow[t]{2}{*}{ Free trade area } & -0.137 & -0.358 & -0.358 & -0.360 \\
\hline & $(0.098)$ & $(0.109)$ & $(0.108)$ & $(0.109)$ \\
\hline \multirow[t]{2}{*}{ Log real GDP importer } & 0.653 & 0.595 & 0.609 & 0.661 \\
\hline & $(0.141)$ & $(0.141)$ & $(0.142)$ & $(0.142)$ \\
\hline \multirow[t]{2}{*}{ Log real GDP exporter } & 0.424 & 0.408 & 0.407 & 0.410 \\
\hline & $(0.164)$ & $(0.170)$ & $(0.170)$ & $(0.169)$ \\
\hline \multirow[t]{2}{*}{ Log population importer } & -0.961 & -0.619 & -0.601 & -0.405 \\
\hline & $(0.290)$ & $(0.431)$ & $(0.431)$ & $(0.431)$ \\
\hline \multirow[t]{2}{*}{ Log population exporter } & 0.009 & 0.605 & 0.607 & 0.600 \\
\hline & $(0.353)$ & $(0.176)$ & $(0.176)$ & $(0.175)$ \\
\hline \multirow[t]{2}{*}{ IMF program } & -0.037 & -0.041 & -0.039 & -0.018 \\
\hline & $(0.029)$ & $(0.029)$ & $(0.029)$ & $(0.029)$ \\
\hline \multirow[t]{2}{*}{ Post-IMF program } & 0.079 & 0.069 & 0.073 & 0.102 \\
\hline & $(0.040)$ & $(0.040)$ & $(0.040)$ & $(0.041)$ \\
\hline \multirow{2}{*}{$\begin{array}{l}\text { Real exchange rate } \\
\text { (multilateral) }\end{array}$} & 0.006 & 0.006 & 0.006 & 0.006 \\
\hline & $(0.001)$ & $(0.001)$ & $(0.001)$ & $(0.001)$ \\
\hline \multirow{2}{*}{$\begin{array}{l}\text { Real exchange rate } \\
\text { (bilateral) }\end{array}$} & 0.001 & 0.001 & 0.001 & 0.001 \\
\hline & 0.000 & 0.000 & 0.000 & 0.000 \\
\hline \multirow{2}{*}{$\begin{array}{l}\text { Mills } \\
\text { ratio }\end{array}$} & & 0.525 & 0.527 & 0.525 \\
\hline & & $(0.103)$ & $(0.103)$ & $(0.103)$ \\
\hline HMR ratio & & 0.370 & 0.369 & 0.375 \\
\hline & & $(0.163)$ & $(0.163)$ & $(0.163)$ \\
\hline Observations & 49068 & 49068 & 49068 & 49068 \\
\hline R-squared & 0.71 & 0.71 & 0.71 & 0.71 \\
\hline
\end{tabular}

Note 1: Standard errors are based on country pair clustering. Separate importer, exporter, and year fixed effects are included but not reported. 


\section{REFERENCES}

Anderson, James, and Eric van Wincoop, 2003, "Gravity with Gravitas: A Solution to the Border Puzzle," American Economic Review, Vol. 93, No. 1, pp. 170-92.

Drazen, Alan, 2003, "Conditionality and Ownership in IMF Lending: A Political Economy Approach,” Staff Papers, International Monetary Fund, Vol. 49, Special Issue.

The Economist, 2005, "Is There Any Point to the WTO?” (August).

Fernandez, Raquel, and Dani Rodrik, 1991, "Resistance to Reform: Status Quo Bias in the Presence of Individual-Specific Uncertainty," American Economic Review, Vol. 85, pp. 1146-55.

Frankel, Jeffrey, and Shang-Jin Wei, 1994, "Yen Bloc or Dollar Bloc: Exchange Rate Policies of the East Asian Economies," in Macroeconomic Linkages: Savings, Exchange Rates and Capital Flows, ed. by Takatoshi Ito and Anne Krueger (Chicago: University of Chicago Press).

Frankel, Jeffrey, 1997, Regional Trading Blocs in the World Economic System (Washington: Institute for International Economics).

Helpman, Elhanan, Marc Melitz, and Yona, Rubinstein, 2005, "Trading Partners and Trade Volumes," Harvard University Working Paper (Cambridge, Massachusetts: Harvard University).

International Monetary Fund, 2001, “Trade Policy Conditionality in Fund-Supported Programs," www.imf.org/external/np/pdr/cond/2001/eng/trade/index.htm

_ - 2005a, "Review of Fund Work on Trade," www.imf.org/external/np/pp/eng/2005/020705.htm , 2005b, "Trade Conditionality Under Fund-Supported Programs, 1990-2004," www.imf.org/external/np/pp/eng/2005/021405.pdf.

— $2005 \mathrm{c}$, "Review of the 2002 Conditionality Guidelines," http://www.imf.org/External/np/pp/eng/2005/030305.htm.

Kaufmann, Daniel, Aart Kraay, and Pablo Zoido-Lobaton, 1999a, "Aggregating Governance Indicators," Policy Research Working Paper No. 2195 (Washington: World Bank).

__ , 1999b, "Governance Matters," Policy Research Working Paper No. 2196 (Washington: World Bank). 
Rose, Andrew, 2002, “Do WTO Members Have More Liberal Trade Policy?” NBER Working Paper No. 9347 (Cambridge, Massachusetts: National Bureau of Economic Research).

— 2004, “Do We Really Know that the WTO Increases Trade?” American Economic Review, Vol. 94, No. 1, pp. 98-114.

Subramanian, Arvind, and Shang-Jin Wei, 2003, "The WTO Promotes Trade, Strongly but Unevenly,” NBER Working Paper No. 10024 (Cambridge, Massachusetts: National Bureau of Economic Research); forthcoming, Journal of International Economics.

Wei, Shang-Jin, 1996, "Intra-National Versus Trade: How Stubborn are Nations in Global Integration?” NBER Working Paper No. 5531 (Cambridge, Massachusetts: National Bureau of Economic Research).

_- 1997, "Gradualism versus Big Bang: Speed and Sustainability of Reforms," Canadian Journal of Economics, Vol. 30, No. 4, pp. 1234-47. Reprinted in The Political Economy of Reform, ed. by Federico Sturzenegger and Mariano Tommasi (Cambridge, Massachusetts: MIT Press, 1998). 